\title{
The Structure and Function of Cutaneous Sensory Receptors*
}

\author{
Bryce L. MUNGER ${ }^{1}$ and Chizuka IDE ${ }^{2}$ \\ Department of Anatomy, The Milton S. Hershey Medical Center ${ }^{1}$, The Pennsylvania State University, Hershey, Pennsylvania, \\ U. S. A., and Department of Anatomy², Iwate Medical University School of Medicine, Morioka, Japan \\ Received March 22, 1987
}

Summary. The present review of cutaneous sensory receptors begins with a consideration of free nerve endings (FNEs) that can be considered as sensory terminals evidencing the least structural specialization of the axon and associated cells. Using the criteria established by KRUGER et al (1981), FNEs of both A delta and $C$ fibers can be identified on the basis of ultrastructural characteristics that include an intimate relationship between axons and the associated epithelium, the lack of a complete Schwann cell investment, the accumulation of numerous vesicles and other cytoplasmic organelles, and for A delta terminals a 1:1 relationship between axon and investing Schwann cell. Using these criteria, the so-called genital end bulbs of the human glans penis are merely a skein of FNEs based on the ultrastructural study of Halata and Munger (1986).

Hair follicles of most species studied to date (the exception being the rabbit and to some extent the guinea pig) are multiply innervated with lanceolate, Ruffini and FNEs. The lanceolate terminals are the rapidly adapting terminals that are numerous in guard hairs. Ruffini terminals of hairs resemble those of the periodontal ligament or joint capsules and both are remarkably similar to Golgi tendon organs in terms of ultrastructural characteristics. The key ultrastructural characteristic is the encircling of collagen bundles by axons and associated Schwann and connective tissue cells.

Axons frequently enter the epidermis either to terminate as FNEs or become associated with Merkel cells in glabrous skin at the base of the papillary ridges or in clusters of Merkel cells in hairy skin in touch domes or Haarscheiben. Merkel cells have clusters of apparent secretory granules polarized toward the axon and the axon is typically a slowly adapting mechanoreceptor. The function of the granules is not known.

Pacinian corpuscles are the largest of the corpuscular receptors of the dermis and are characterized by an elaborate inner core of stacks of numerous thin lamellae arranged in a bilaterally symmetrical manner. Based on the fact that the lamellae are coupled with gap junctions and the outer core lamellae isolated by numerous tight junctions, the authors have proposed that the unique ionic environment may be in part responsible for the remarkable sensitivity of Pacinian corpuscles (MUNGER and IDE, 1987).

Meissner corpuscles are a typical corpuscular receptor of murine (IDE, 1976, 1977), marsupial and primate glabrous skin (MUNGER, 1971). The axons typically weave back and forth between stacks of lamellae. Simple corpuscles are common in many mammals especially in the glabrous snout skin (MUNGER, 1965, HALATA and MUNGER, 1983). The lamellae around the axon are typically arranged circumferentially around the axon.

The authors have previously noted that axons in mechanoreceptors including lanceolate terminals, Pacinian and Meissner corpuscles, and muscle spindles frequently have axonal spines projecting from the elongated or Y-axis of the axon (MUNGER and IDE, 1987). Axonal spines typically are filled with filaments and lack other cytoplasmic organelles. The common presence of axonal spines provided the basis for the speculation that they may be involved in mechano-electric transduction.

The sensory receptors of the skin constitute one of the five exteroceptive systems that provide the body with information concerning conditions of the external world. The other exteroceptive systems are the special senses subserving sight, hearing, smell and taste. The sensory systems of the skin are classically defined or characterized by the type of sensation perceived by the human observer, and we can perceive touch, warmth, cold, and pain with our skin. These specific sensory qualities are termed modalities, and they represent changes in thermal or mechanical energy delivered to the skin (DARIANSMITH, 1984a, b; PERL, 1984). In contrast to the thermal senses and light touch that represent transduction of only one form of energy, pain can be produced

\footnotetext{
*The present report was supported in part by USPHS Research Grant \#NS 19462 and the Japan Society for the Promotion of Sciences.
} 
by a change in either thermal or mechanical energy that potentially could produce tissue damage. Each modality is represented by the transfer of energy into the skin and transduction by a specific type of axonal terminal-a statement that we could not make in a previous review (MUNGER, 1971). Some axon terminals are polymodal, i.e., they respond to more than one type of energy. The most common polymodal receptors are polymodal nociceptors with the receptor responding to noxious mechanical as well as thermal stimuli. The specific types of sensory receptors associated with the transduction of each form of energy will be reviewed beginning with free nerve endings (FNEs) thought to be the receptors responsible for the transduction of thermal and painful stimuli (DARIAN-SMITH, 1984b; PERL, 1984).

The present review of cutaneous sensory receptors was prompted by the observations of IDE and HAYA. SHI (1988) that the inner and outer cores of Pacinian corpuscles have distinctive intercellular membrane specializations. The present authors used these observations to re-examine the cytology of cat Pacinian corpuscles (IDE et al., 1988; MUNGER et al., 1988) and to review the unusual features of mechano-electric transduction of Pacinian corpuscles (MUNGER and IDE, 1987). This series of papers raised numerous questions regarding the functional properties of mechanoreceptors in general and prompted the present review of all cutaneous sensory receptors in the hopes of providing an overview of the strucuture and function of cutaneous sensory receptors. Our approach will be to emphasize mammalian skin and especially human where possible.

The following discussion will follow the general format of a previous review by one of the authors (MUNGER, 1971) in which the basic patterns of innervation of both glabrous and hairy skin were compared. All mammals have skin characterized either by the presence or absence of hairs referred to as hairy or glabrous skin. All mammals other than man also have numerous vibrissae or sinus hairs. Facial vibrissae are furthermore segregated in a special patch lateral to the nares referred to as the mystacial pad in all non-primate mammals. Man is the only mammal lacking vibrissae. Monkeys have numerous vibrissae arranged geometrically over the entire face (HALATA and Munger, 1980a; Munger and Halata, 1983). We thus can recognize two types of hairy skin: the pelage of the general body surface and skin bearing vibrissae. The intervibrissal skin has typical pelage (RICE et al., 1986; RICE and MUNGER, 1986).

Glabrous skin also has two characteristic subtypes, i.e., skin with papillary ridges that are reflected onto the skin surface as a fingerprint and glabrous skin that lacks a distinctive fingerprint. We propose that glabrous skin lacking fingerprints be referred to as adermatoglyphic glabrous skin. Skin characterized by the presence of large papillary ridges and associated fingerprints would be referred to as dermatoglyphic glabrous skin. All primates and most marsupials as well as some rodents (OKAJIMA and ASAI, 1985) studied to date have dermatoglyphic glabrous palmar and plantar skin as noted by LOESCH (1983), and MIDLO and Cummins (1942). Some glabrous skin especially in marsupials lacks true papillary ridges and contains only rete ridges. Rodents as described by OKAJIMA and ASAI (1985) have ridges of irregular width and lacking the regular array of sweat glands thus differing somewhat from the extremely regular ridges present in primates and marsupials. SILVERMAN et al. (1986) also documented the presence of ridges in the glabrous skin of the rat snout.

The pattern of innervation of these two types of hairy and glabrous skin differ in subtle ways as will be pointed out subsequently. As noted by HaLATA and MUNGER (1983) peripheral cutaneous sensory receptors are organized around the epidermal specializations of both glabrous and hairy skin (DELL and MUNGER, 1986) and this conclusion had been clearly stated previously by MiLler et al. (1958). Understanding the nature of the cutaneous derivatives (hairs and papillary ridges) is thus the key to understanding the nature of cutaneous sensory innervation.

The previous review by MUNGER (1971) opened with a consideration of the dermal nerve net. At that time, considerable doubt was expressed as to the possibility of characterizing the dermal nerve net and more specifically the free nerve endings (FNEs) within the dermal nerve network. FNEs are thought to be the nerve terminals of A delta and unmyelinated axons (C fibers) subserving the modalities of pain and temperature (DARIAN-SMITH, 1984b; PERL, 1984). The problem in identifying and characterizing FNEs is the difficulty in knowing that we are indeed examining the end of the axon. As noted below, considerable progress has been made in the characterization of this most ubiquitous component of the peripheral sensory nervous system. Free nerve endings are present in both glabrous and hairy skin and thus are present throughout the entire cutaneous surface. Following a consideration of the dermal nerve net and FNFs, we will progress to a consideration of the types of terminals present on guard and vellus hairs followed by Merkel terminals in both glabrous and hairy skin. We will then review corpuscular receptors that are typically more prominent in glabrous skin. 
We will close with a brief review of vibrissae as they represent a synthesis of the receptors present in glabrous and hairy skin.

\section{FREE NERVE ENDINGS AND THE DERMAL NERVE NET}

The dermal network of nerves is typically described as having both a superficial and deep component and this network can be visualized in both glabrous and hairy skin (MUNGER, 1982). The problem confronting an analysis of this network is the difficulty in know- ing that one is examining the end of an axon by electron microscopy (MUNGER, 1971). A second problem is that the receptors must be characterized physiologically in order to identify the terminals as nociceptors or thermal receptors. The first problem was approached by CAUNA (1973) using serial sections studied by electron microscopy. Cauna identified the free endings of $\mathrm{C}$ fibers as "penicillate nerve endings" and noted the frequent absence of investing Schwann cells with the axon directly abutting the basal lamina and frequent intimate association with the epithelium. Similar conclusions were noted by KRUGER et al. (1981) in an ultrastructural study of physiologically

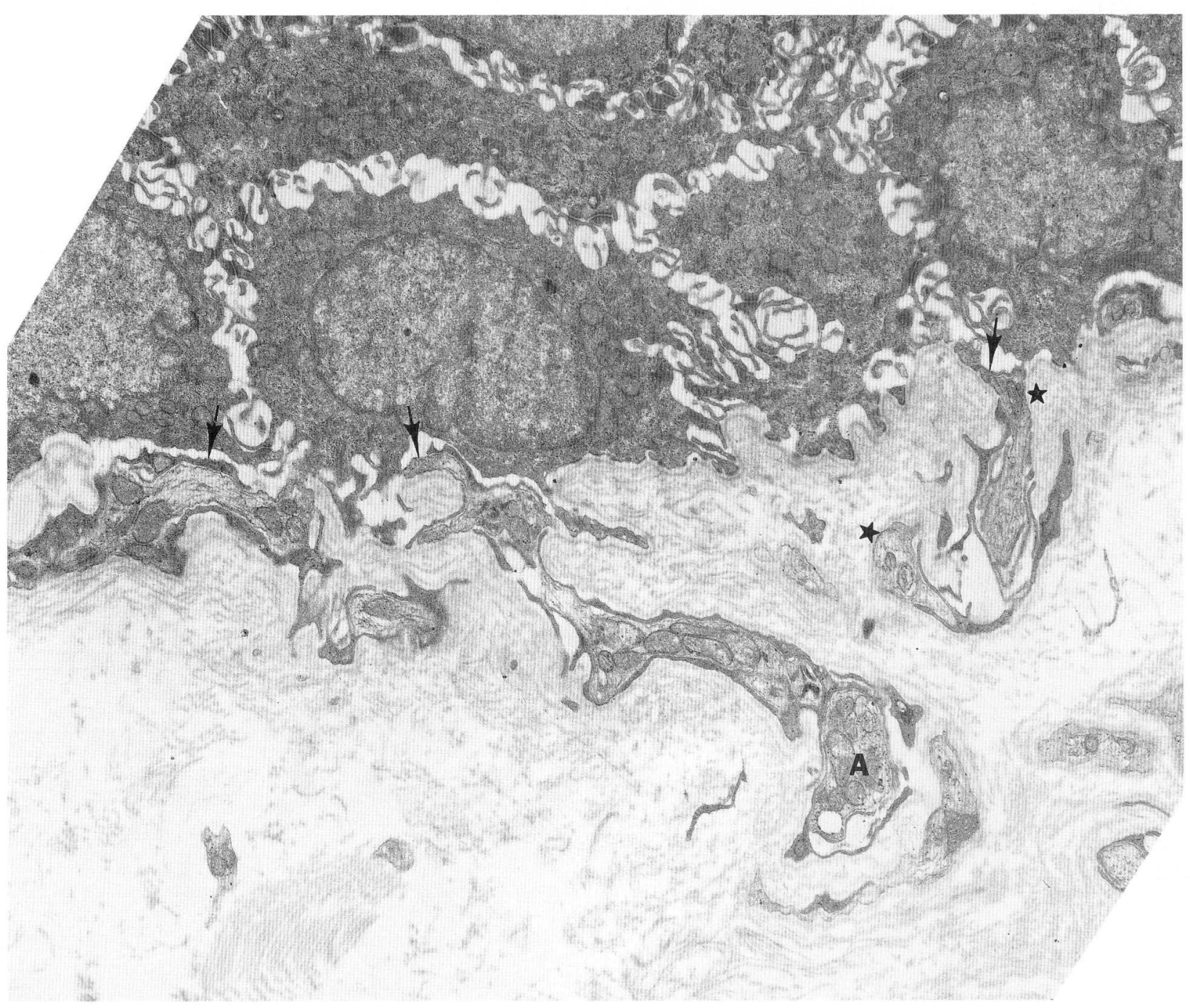

Fig. 1. Free nerve ending, rat penis. This micrograph was published as an example of intraepidermal nerves not associated with Merkel cells (PATrizi and Munger, 1965). At that time we were unable to identify this terminal as an FNE. As described in more detail in the text, this terminal represents branches of a central axon $(A)$ and the branches (arrows) enter the epidermis. At the arrows no basal lamina separates the axon from epidermal cells. The axons have numerous sites where a Schwann cell ensheathment is lacking $($ stars $) . \times 9,000$ 


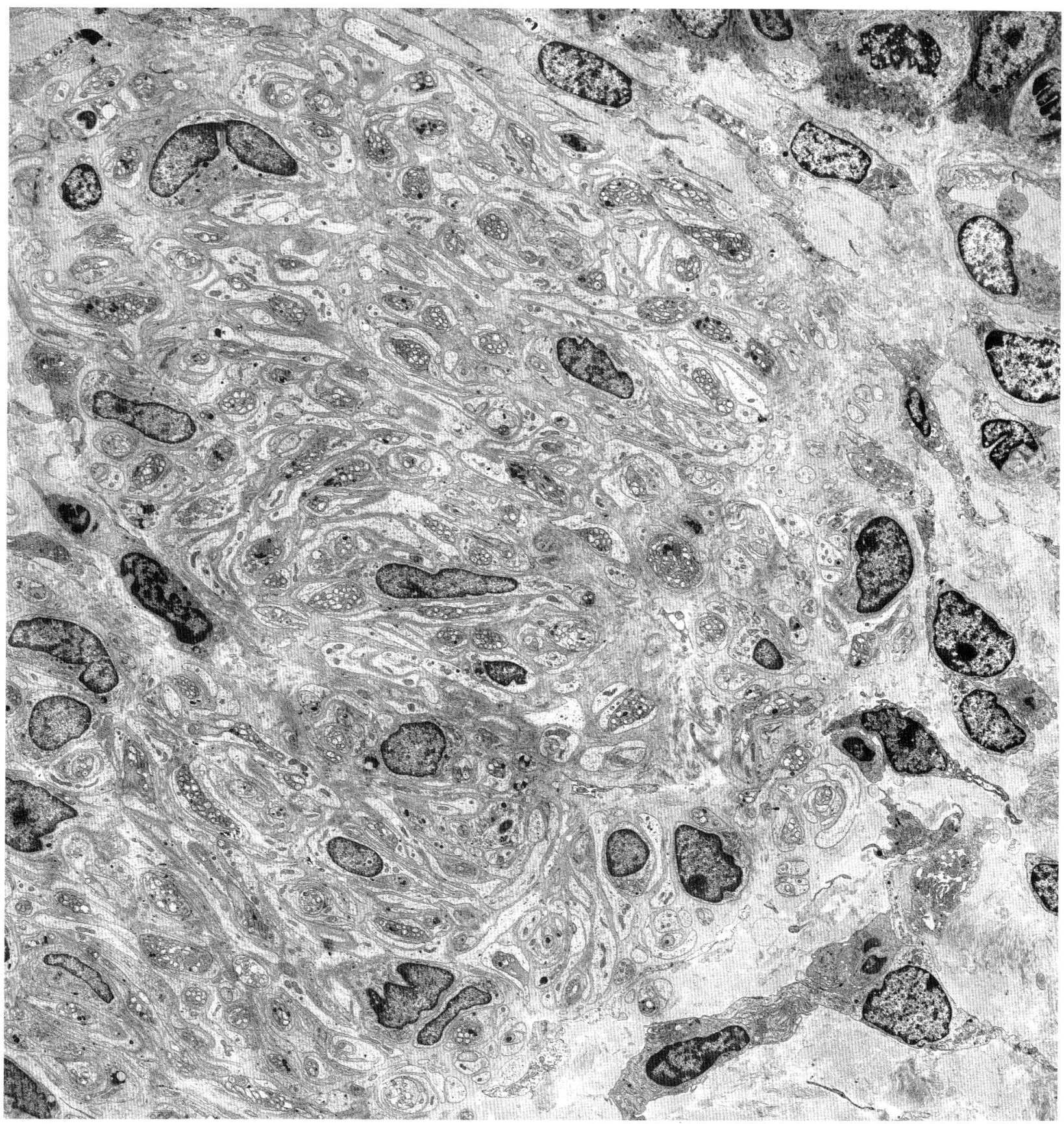

Fig. 2. Genital end bulb, human glans penis. The tangled skein of axons to the center and left of the micrograph resembles the FNE illustrated in Figure 1. Numerous lamellae are not present between the axons as is the case in Meissner and simple corpuscles. The epidermis is present to the upper right. This micrograph was kindly provided by $Z$. HALATA. $\times 2,400$

defined nociceptors in cat hairy skin. The remarkable similarity of endings noted by Cauna and those of Kruger's study provide a convincing demonstration of the simil rity of FNEs of $\mathrm{C}$ fibers and A delta fibers. The A delta terminals are perhaps easier to identify as they have a 1:1 relationship of axon and investing Schwann cell (Fig. 1). However at a cytological level, they are very similar and in fact resemble endings previously published in the rat penis by PATRIZI and MUNGER (1965) and raccoon glabrous skin by MUNGER 
and Pubols (1972). The latter may be an example of a thermal receptor as it resembles in some features the presumptive thermal receptor described by HENSEL (1973).

MUnger and Halata (1983) used the criteria established by KRUGER et al. (1981) to identify FNEs in the conus region of the capsule of monkey sinus hairs or vibrissae, a site where other sensory receptors were not present, and the axon terminals appeared to be identical to the terminals noted in the above studies by CAUnA (1973) and KRUGER et al. (1981). In all cases, FNEs are characterized by a 1:1 relationship of axon and Schwann cell for A delta fibers, and for both A delta and $\mathrm{C}$ fibers the axons at their terminals directly abut the basal lamina, tend to have accumulation of cytoplasmic debris, and are frequently intimately related to the associated epithelial compartment, i.e., hair follicle, epidermis, or sebaceous gland.

The intimate relationship noted by KRUGER et al. (1981) for FNEs and the epithelial compartment permits the characterization of both dermal and epidermal FNEs in the skin (HALATA and MUNGER, 1983). In the absence of physiological definition, the identification of any FNE is presumptive especially in a cutaneous surface that also has Merkel cells (HAlata and Munger, 1983). Since Merlel cells are a ubiquitous component of all skin, caution must be exerted in the characterization of all FNEs on cytological ground alone. By light microscopy, presumptive characterization of FNEs is possible especially in thick sections stained with silver where the course of the axon can be determined in three dimensions (MUNGER, 1982).

The cytologic definition provided by KRUGER et al. (1981) for A delta polymodal nociceptor FNEs needs to be extended to other nociceptors as well as thermal receptors. Dating from the classic studies of BLIX (1884), GOLDSCHEIDER (1886) and VON FREY (1894a, b, 1895) the punctate nature of pain, temperature, and touch spots in human skin has been repeatedly documented. Yet to date, only the study of KRUGER et al. (1981) has correlated one of the sensory modalities thought to be associated with FNEs with a cytological analysis of the associated FNE. The tactile receptors in hairy skin as noted below are the hair follicles themselves (see MUNGER, 1982) or Haarscheiben of PINKUS (1905) (touch domes of IGGO and MuIR, 1969) located between the hairs. But hairs have FNEs associated with them as part of their multiple repertoire of sensory receptors as noted in detail by MUNGER (1982). The FNEs of hair follicles are present surrounding the typical lanceolate terminals as noted below.

FNEs are present in great abundance in the human glans penis as described by HALATA and Munger (1986). Not only are large numbers of FNEs present in the dermis but the large corpuscles (Fig. 2) thought to be specific for the glans penis and clitoris consist of a skein of FNEs using the criteria described by KRUGER et al. (1981). The epithelium of the human glans penis does not contain the sensory receptors characteristic of glabrous palmar, plantar or labial skin (HAlata and Munger, 1983) as described in detail below. Even more remarkable is the fact that their conclusion that the glans sensory nerves are almost exclusively FNEs is consistent with the sensory perception of the human glans as described by VON FREY (1894a, b) and confirmed in great detail by RIVERS and HEAD (1908). The glans is simply insensitive to light touch with a threshold in actual force resembling that of a callus on the sole of the foot. Stated another way to make the point that the glans is unique: the threshold for touch is actually the pain threshold. This remarkable fact was part of the basis for RIVERS and HEAD (1908) concluding that the glans was only capable of perceiving protopathic sensations.

The opposite is true for glabrous digital sk in where the touch threshold is extremely low and the pain threshold high (HALATA and Munger, 1986). The absence of Meissner corpuscles and Merkel terminals in the glans can also be correlated with the thermal responses of the glans. VON FREY (1894a, b) as well as RIVERS and HEAD (1908) all noted the unusual responses of the glans to cold stimuli, and as reviewed by HaLATA and MUNGER (1986) this also consistent with the pattern of FNFs in this unusual cutaneous surface. They also note that developmentally the glans is not covered with epidermis typical of the general body surface, but rather develops as the result of an ingrowth from the epidermis that secondarily splits to free the prepuce from the surface of the glans. Thus the glans is not covered with a typical skin surface and is an exception to the general pattern of cutaneous innervation.

\section{THE PILONEURAL COMPLEX}

Hairy skin of man and other mammals typically has two major types of hair follicles: Guard hairs have large diameter hair shafts such as human scalp hair and the outer long hairs of furred animals and 2) vellus hairs that are smaller in diameter such as the down hairs of furred mammals. In some cases vellus 
hairs barely project from the skin surface such as on the surface of the human eyelid (HALATA and MuN. GER, 1980b). The pattern of sensory innervation is also different as one compares guard and vellus hairs (Munger, 1982). Both types of hairs have multiple unique sensory terminals of differing physiological parameters. In both cases, however, the collar of sensory innervation is wrapped around the hair follicle just below the duct of the sebaceous gland if one is present. This generalization is true for all hairs described to date by light or electron microscopy.

All sensory receptors are characterized physiologically by their modality specificities and adaptive properties (DARIAN-SMITH, 1984a). We have presented previously the modalities that are characteristic of FNEs, i.e., pain and temperature. We noted above that the touch receptors of hairy skin are in fact the hairs and their collar of sensory innervation, hence the term piloneural complex (RICE and MUNGER, 1986). The exquisite sensitivity of scalp or eyebrow hairs to mechanical deflection of even $1 \mathrm{~mm}$ is no less of an enigma than Pacinian corpuscles as to the nature of the mechanical stimulus transduced at the level of the receptor (MUNGER and IDE, 1987).

The adaptive properties of sensory axons in hairy skin can be typically classified as slowly or rapidly adapting. The slowly adapting (SA) receptors signal sustained mechanical displacement and the rapidly adaping (RA) receptors signal the onset or cessation of a mechanical displacement. Mechanical transients would activate RA units and pressure to the skin would activate SA units. Hairs are typically innervated by both RA and SA mechanoreceptive axons (MUNGER, 1982).

Guard hairs typically are innervated by a collar of lanceolate terminals surrounded by Ruffini and FNEs. Lanceolate terminals are arranged like the types of a fork, to quote HoGGan and HoGGAN (1892/ 93). A small nerve bundle typically approaches a hair follicle from below and the axons will undergo a few

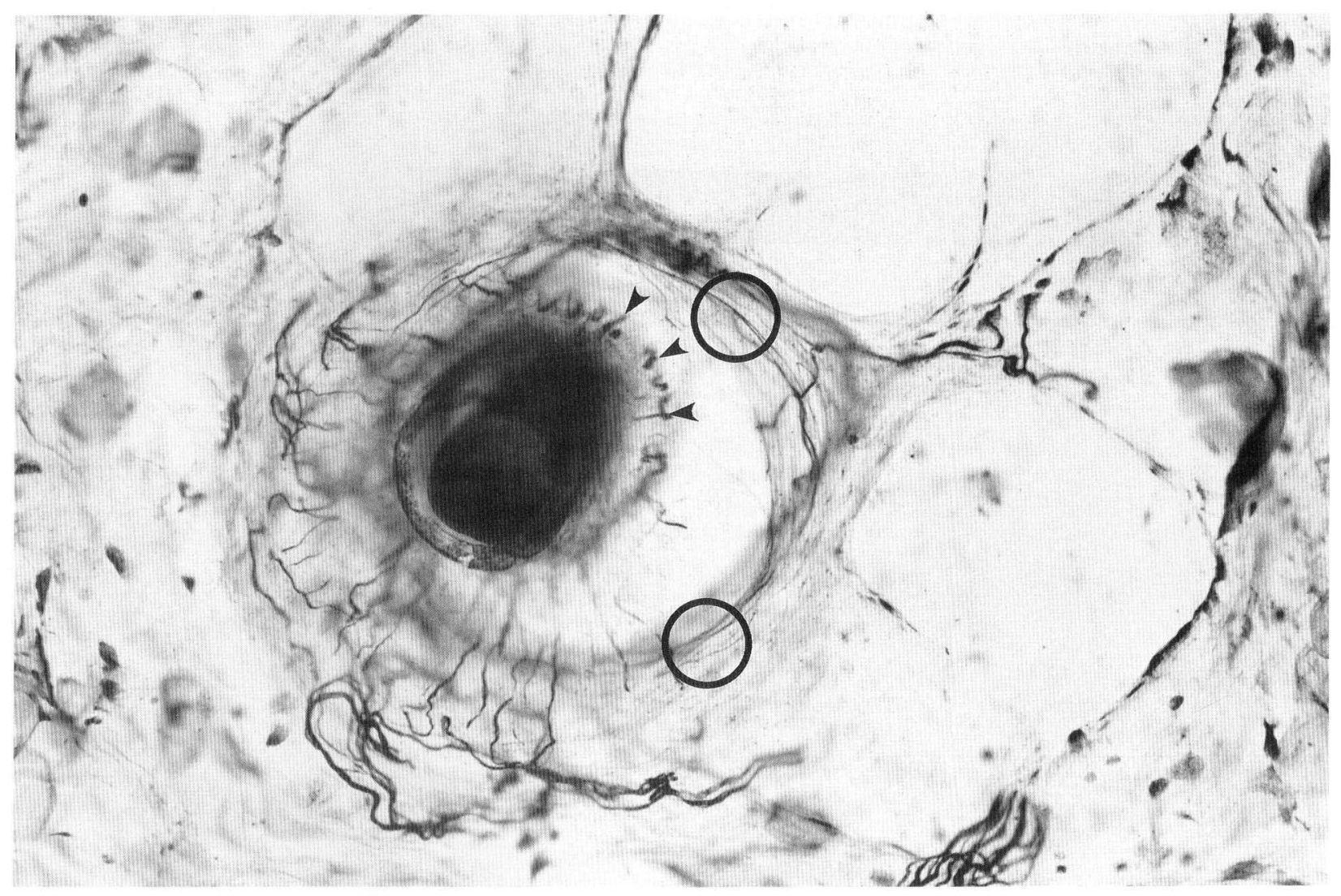

Fig. 3. Piloneural complex, monkey guard hair. The palisade of lanceolate terminals (arrowheads) ascends the hair shaft tightly abutting the external root sheath. The circular Ruffini terminals and FNEs (circles) surround the lanceolate terminals. This section is $100 \mu \mathrm{m}$ thick and stained with Winkelmann's silver technique. This micrograph was published previously by MunGER (1982) and republished with the permission of the publisher. $\times 240$ 
terminal divisions immediately prior to forming the lanceolate terminals. The axons of laceolate terminals are shaped like a flattened cylinder sandwiched between two Schwann cell processes. When viewed in cross section, the axon thus has a short $\mathrm{X}$-axis and elongated $\mathrm{Y}$-axis using the terminology applied to the elliptical cross section of the central axon of Pacinian corpuscles as proposed by Munger et al. (1988). The lance-like configuration of the ending was noted originally by BONNET (1878). ANDRES (1966) coined the term in modern usage, and the present authors have consistently used the term lanceolate terminal to characterize the typical sensory terminals on hairs (Munger, 1971; Bressler and Munger, 1983; Mun GER and Halata, 1983; RICE and MungER, 1986;
Renehan and Munger, 1986a, b; Munger and Ide, 1987).

The lanceolate terminals always have a special relationship to the basal lamina of the external root sheath of the hair follicle (Fig. 4). The sharp or flattened $\mathrm{Y}$-axis face of the axon typically directly abuts the basal lamina of the external root sheath with no intervening Schwann cell cytoplasm. Small axonal spines typically project from $\mathrm{Y}$-axis faces of the axon that are not invested with Schwann cell cytoplasm. Axonal spines are small projections of axoplasm containing numerous filaments that are characteristic of many mechanoreceptors. Axonal spines were originally described in Pacinian corpuscles as microspikes by SPENCER and SCHAUMBURG

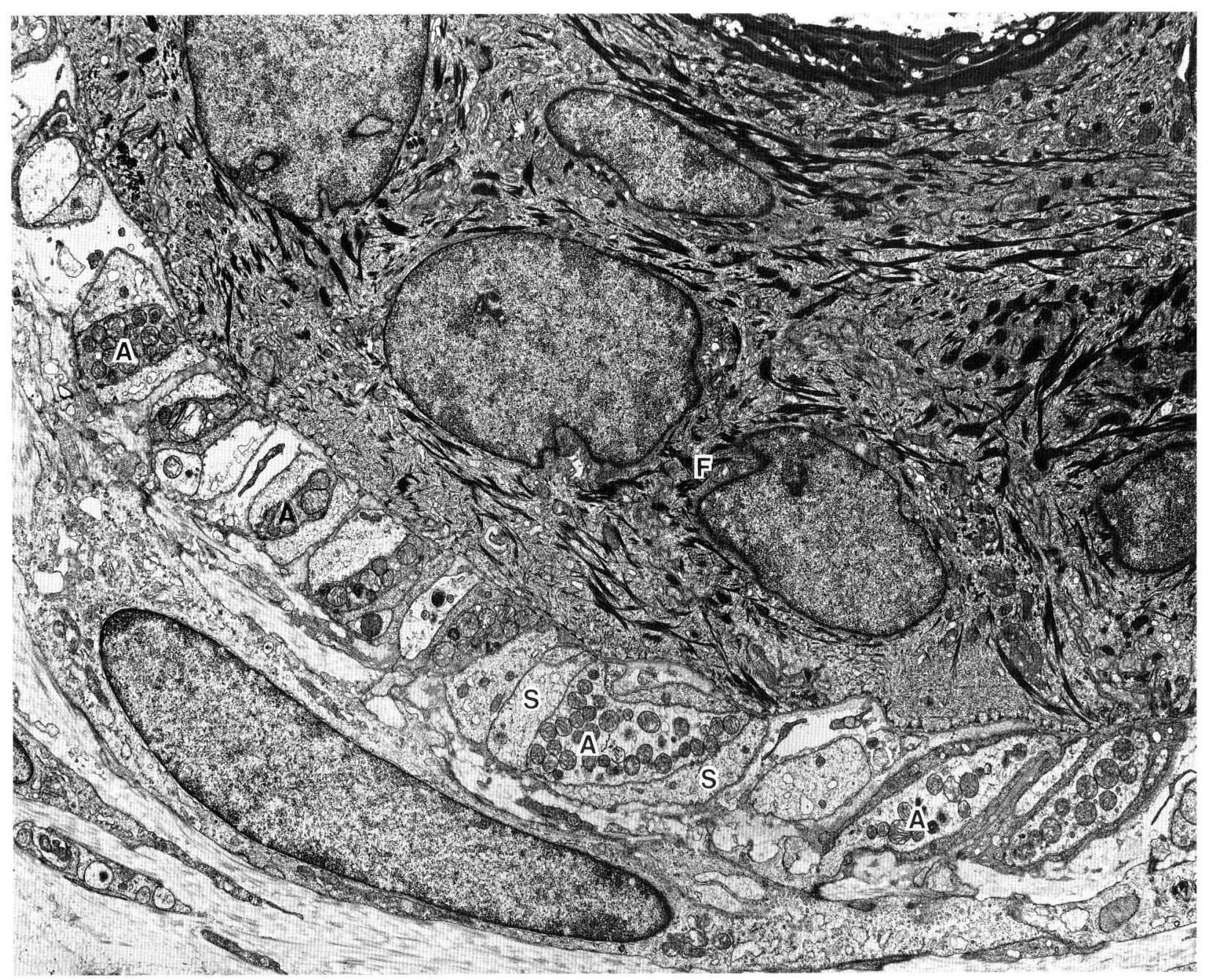

Fig. 4. Lanceolate terminals on the hair follicle of monkey. This micrgraph shows a cross section of the axon terminals arranged in a lance-like fashion around the follicle $(F)$. Axon terminals $(A)$ are flattened, being sandwiched by Schwann cell processes $(S)$ on the X-axis, and directly abut the basal lamina of the external root sheath of the hair follicle with $\mathrm{Y}$-axis face. $\times 15,500$ 
(1973), but the present authors (MUNGER et al., 1988) have suggested that all such projections of sensory axonal terminals should be referred to as axonal spines. The axonal spines of lanceolate terminals not only abut the basal lamina of the external root sheath, but similar processes are present on the other $\mathrm{Y}$-axis face of the axon. The two Schwann cell processes that tightly abut the $\mathrm{X}$-axis faces of the axon have numerous pinocytotic vesicles and no basal lamina is present between the Schwann cells and the axon. Basal lamina is present surrounding the Schwann cells processes and the bare $\mathrm{Y}$-axis faces of the axon.

The lanceolate terminals of guard hairs are typically ringed externally by circular fibers (Fig. 3) that have been identified as Ruffini terminals (BIEMESDERFER et al., 1978) and FNEs that are innervated by axons from the superficial portion of the dermal nerve net (lanceolate terminals are innervated by the deep plexus) (Munger, 1982). Munger and Halata (1983) verified these light microscopic observations and described the ultrastructure of the innervation of primate guard and vellus hairs. RICE and MUNGER (1986) extended these observations to include guard hairs of other mammals.

The first suggestion that hairs might be multiply innervated can be found in the writings of Henry HEAD (HEAD and Sherren, 1905; Rivers and HEAD, 1908). The dates of these two papers are important in trying to understand why HEAD would say that it is obvious that hairs have multiple sensory nerves. The report in 1908 is the detailed description of the regeneration of nerves into his own skin that had been denervated experimentally in 1903. The statement about the hairs being multiply innervated is only described in detail in the 1905 paper that was a clinical summary of his experiences in the Boer War. However, he already knew that not only did he himself have hairs that had no pain fibers, but he had observed this finding in some of his patients with peripheral nerve trauma as well. He simply described the presence of hairs that could be tugged and were not painful. MUNGER and SCHNEIDER (1986) have presented in abstract form a similar human case in which only lanceolate terminals could be identified by light and electron microscopy. Thus lanceolate terminals are the sensitive touch receptors and are the RA units of hairy skin.

The SA units of the piloneural complexes are Ruffini terminals as described in detail by BIEMESDER. FER et al. (1978). This study was prompted by DuB. NER's observation that SA units could be found on small hairs in primate facial skin, and the collabo- rative study was undertaken to determine the nature of the hairs involved. As noted below, Merkel terminals are SA sensory receptors in both glabrous and hairy skin. Vibrissae or sinus hairs are known to have Merkel terminals (PATRIZI and Munger, 1965; ANDRES, 1966). No vibrissae were present in the majority of hairs studied by BIEMESDERFER et al. (1978) although all had slowly adapting units. The distinctive cytologic feature of these SA non-vibrissal hairs was the presence of nerve terminals around the lanceolate terminals with ultrastructural characteristics that we argued were characteristic of a Ruffini terminal. HALATA (1977) independently and concurrently found identical terminals in a joint capsule and correctly identified them as Ruffini terminals. HALATA and Munger $(1980 \mathrm{a}, \mathrm{b}, \mathrm{c}, 1981,1983)$ in a series of collaborative efforts confirmed the identification of Ruffini terminals in a variety of sites. Perhaps buried in this list is the fact that Ruffini terminals can be found in birds (HALATA and MUNGER, 1980c). Golgi tendon organs are also present in both mammals and birds as noted by HAIDEN and AWAD (1981) in their study of avian tendon organs. As noted below, Golgi tendon organs are ultrastructurally identical to Ruffini terminals. Ruffini terminals, Golgi tendon organs and FNE's are cutaneous sensory terminals typical of both mammals and birds.

The Ruffini terminal can be identified by its distinctive light and electron microscopic appearance (BIEMESDERFER et al., 1978). At a light microscopic level it consists of fine terminal axon branches that course circumferentially around the hair follicle. In a joint capsule or dermis the axon branches repeatedly and terminates in small arc-like expansions that appear distinctive in RUFFINI's original preparations (Halata, 1977). Figures 5 and 6 have been kindly provided by Dr. T. MAEDA from the periodontal ligament and the tissue has been stained to demonstrate neurofilament protein (Fig. 5). The surrounding Schwann cells have S-100 protein as described in more detail by SATO et al. (1988) and MAEDA et al. (1987). While these examples are not taken from the skin we are including them as examples of the accuracy of identification of these terminals. As reviewed by BIEMESDERFER et al. (1978), Ruffini went to great lengths to assert that "his receptor" was not identical to a Golgi tendon organ. The distinctive ultrastructural feature is the fact that the terminal axons and their associated Schwann cells encircle bundles of collagen (BYERS, 1985 ; NiTA TORI, 1988) (Fig. 6). Other cells within the Ruffini terminal also encircle and compartmentalize bundles of collagen but these cells are not Schwann cells as they do not envelope axons 


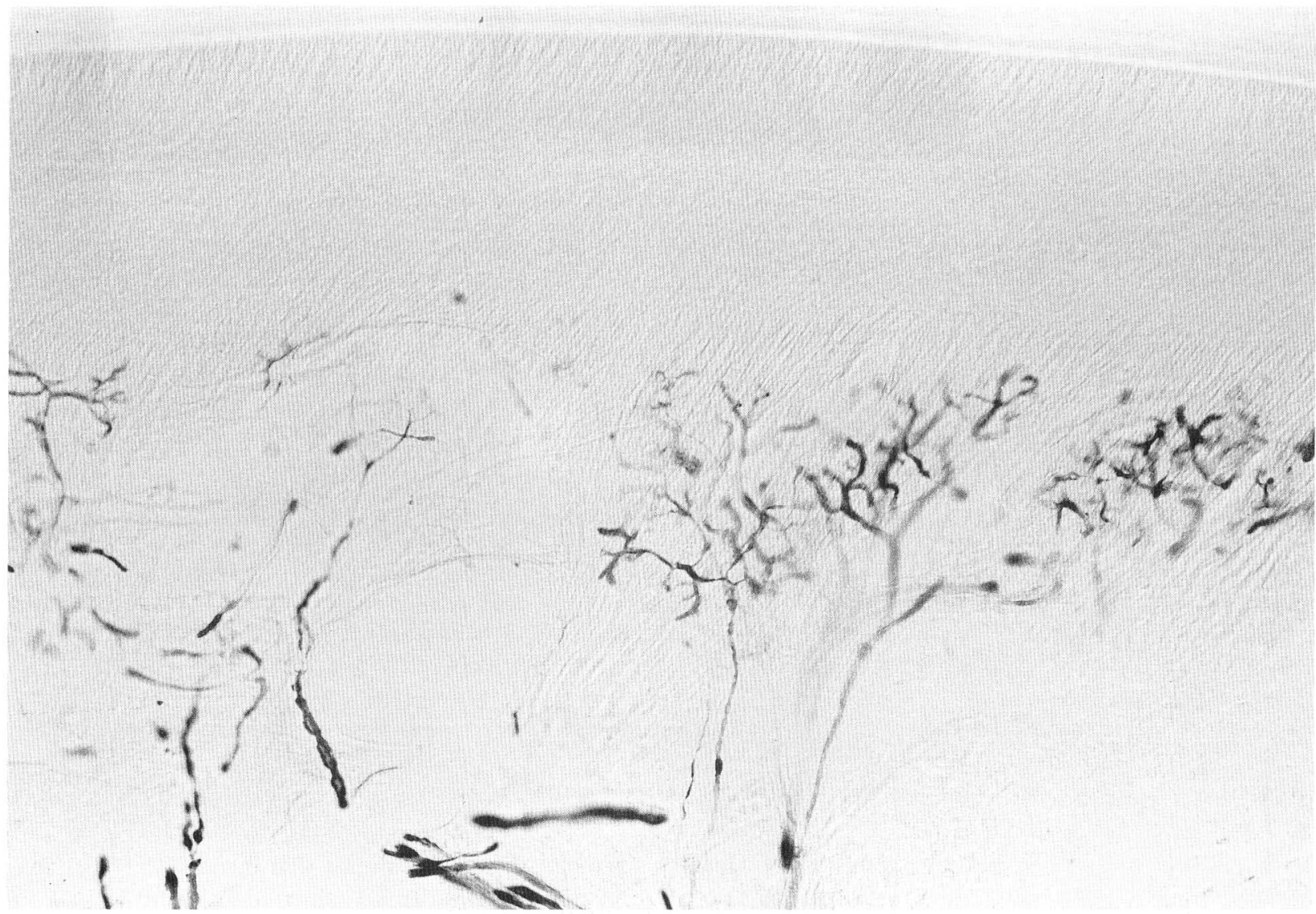

Fig. 5. Lingual periodontium of the rat incisor immunoreactive (PAP method) for neurofilament protein (NFP). Several thick nerve bundles enter the ligament from the bottom of the micrograph and ramifies with dichotomous branching. The terminal axons appear to envelope bundles of connective tissue thus fulfilling the criteria for the identification of Ruffini terminals. Micrograph courtesy of T. MAEDA. $\times 240$

and they lack a basal lamina. This second cell type has been called septal cell (Schoultz and SwETT, 1972). This latter study documments the ultrastructure of Golgi tendon organs, and at an ultrastructural level the two receptors are almost identical. This conclusion has been verified by ZELENÁ and SoUkUP (1977). Ruffini would not be happy with this conclusion. The site is the only distinctive difference between Golgi tendon organs and Ruffini terminals, and both are SA receptors.

Using the criteria cited above for the identification of FNEs, we can also find FNEs associated with the piloneural complex as described by Munger(1982). FNEs are typically found external to the collar of Ruffini endings. In the example studied by MUNGER and SchNEIDER (1986), the Ruffini collar and the external FNEs were all denervated. Only lanceolate terminals remained. As reviewed by MUNGER (1971), the distinction of lanceolate and circular fibers was nebulous at best. The drawing in that review is simply incorrect. On the basis of the list of studies cited above, we are now comfortable in the identification of Ruffini and FNE terminals. RENEHAN and Munger (1986a) applied these principles to the identification of the sensory terminals in sinus hairs or vibrissae by electron microscopy, and subsequently RICE et al. (1986) extended these findings to other terminals in vibrissae as well.

The practical value of having SA and RA units on the same cutaneous derivative as well as presumptive nociceptors is the fact that parallel processing begins at the level of the sensory receptors in the skin. As reviewed by Diamond (1973), MERzENich and KAAS (1980), KAAS et al. (1981) and DyKes (1983), parallel processing is a general phenomenon in cutaneous neurophysiology. However, it also is seen in other sensory systems as well such as the visual (LENNIE, 1980) and auditory system (WARR, 1982). One way of expressing the importance of the concept is the statement that without parallel processing we would not 
be able to read braille with our fingers or read the printed page with our visual system. While physiological principles contained in the concept of parallel processing are typically stated with respect to primary and secondary afferents, we can additionally note that parallel processing actually begins at the level of the sensory receptor on individual cutaneous derivatives. Thus, rete ridges of glabrous skin and hairs of hairy skin are all multiply innervated and in addition, as we will note later, are innervated by multiple spinal segments as well (MUNGER, 1983).

In contrast to the elaborate piloneural complexes present on guard hairs, vellus hairs typically have scant lanceolate terminals and only rarely have a Ruffini terminal. FNEs as one might expect are present throughout hairy skin and are frequently seen in primate (MUNGER, 1982) or other mammalian vellus hairs (RICE and MUNGER, 1986). It is, however, important to note that by light microscopy it is possible to identify Ruffini terminals on occasional primate vellus hairs (MUNGER, 1982). In addition, Halata and Munger (1981) have identified Ruffini terminals in human hairy skin. The rare occurrence of Merkel cells in human guard hairs will be discussed at the end of the section of Merkel cells.

\section{INTRAEPIDERMAL INNERVATION AND MERKEL CELL-NEURITE COMPLEXES}

From the perspective of the present authors it is difficult to explain the resistance to the concept that Merkel cells were a significant biological entity when they were first visualized in electron micrographs (MUNGER, 1965). At that time, specificity of sensory receptors was an unpopular concept (see MUNGER, 1982). The prevailing sentiment was that only the pattern of cutaneous peripheral innervation had meaning for interpretation of modality specificity. This concept was developed using the rabbit ear as the model as described by WedDELL $(1941,1960)$ and

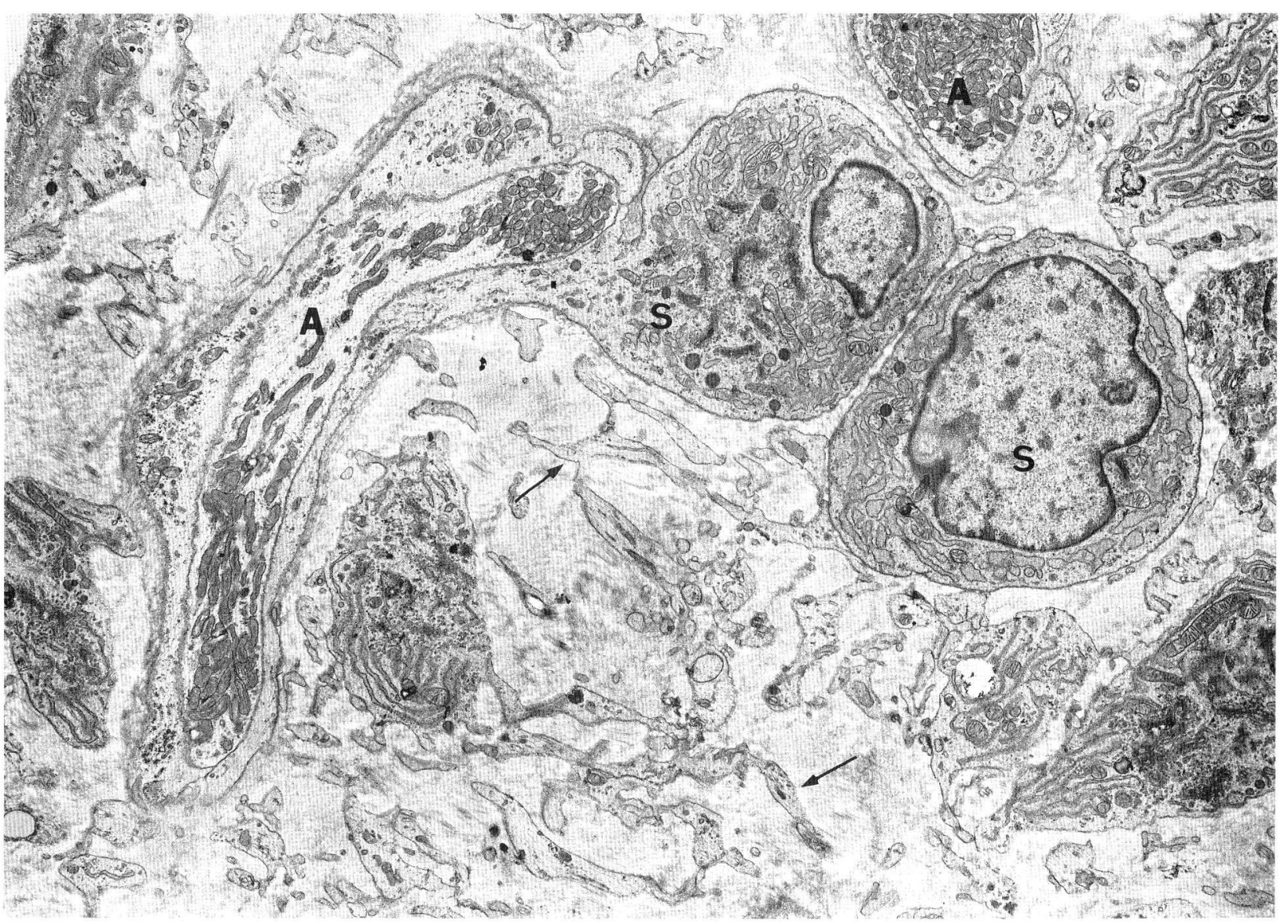

Fig. 6. Rat periodontium, Ruffini terminal. Axons $(A)$ and associated Schwann cells $(S)$ compartmentalize the dense collagen bundles of the periodontal ligament. Septal cells (arrows) lacking a basal lamina and without direct contact with axons also compartmentalize the connective tissue. Micrograph courtesy of T. MAEDA. $\times 6,000$ 
WedDELl and Miller (1962). As noted by Rice and MUNGER (1986), the rabbit has the most unusual pattern of pelage innervation of all mammals that they have studied to date. Rabbit piloneural complexes lack Ruffini terminals and the lanceolate terminals do not form a regular palisade or array. The rabbit simply lacks a typical mammalian piloneural complex. Since this publication in 1986, RICE and MUNGER (unpublished observations) have evaluated the peripheral pattern of innervation of six additional species and the generalization holds: the rabbit is a unique mammal, and close to the rabbit is the guinea pig. Even the opossum (Didelphis and Monodelphis) have guard hairs that are innervated like primates including man as do all insectivores and rodents. Considering the fact that the oposum has a fossil record dating 50 million years, we regard the pattern of sensory innervation of guard and vellus hairs as well as vibrissae as being very conservative in evolutionary terms.

Merkel cells are now regarded as a ubiquitous component of both hairy and glabrous skin, but their location is slightly different. In hairy skin Merkel cells are typically found in dome-like elevations of the skin referred to as Haarscheiben or touch domes that were originally described by PINKUs (1905). The Merkel terminals in glabrous skin are found at the base of the papillary ridges between each sweat duct of the papillary ridges as described in detail by PEREZ $(1931 / 32)$. In skin lacking papillary ridges such as the glabrous skin of the opossum snout, the Merkel cells are found at the base of the rete pegs as described by MUNGER (1965). A similar pattern of organization is seen in the raccoon glabrous digital skin as it consists of rete pegs also (MUNGER and PUBols, 1972). The prominent clusters of Merkel cells in the raccoon have been referred to as Merkel rete papillae by MunGer and Pubols (1972).

In both glabrous and hairy skin, axons associated with Merkel cells are SA mechanoreceptors as defined in hairy skin by IGGO and MUIR(1969) and glabrous raccoon (MUNGER and PUBOLS, 1972) and primate skin (MUNGER et al., 1979). As noted above, the opossum has a long fossil record indicating that Merkel cells are phylogenetically ancient. Furthermore, similar cells are present in submammalian vertebrates including lizards (LANDMAN and HALATA, 1980) salamanders (SCOTT et al., 1981) as well as lampreys (WHITEAR and LANE, 1981). We do not have functional data on all of these species, but the study by ScoTt et al. (1981) clearly demonstrates the fact that the nerves associated with amphibian Merkel cells are RA units. Birds remain a problem as the cells identified as Merkel cells (SAXOD, 1978) are considered to be dermal Grandry cells by IDE and Munger (1978). The adaptive properties of avian Grandry corpuscles is also not clear. Further studies of comparative nature are clearly needed.

The above statements imply that Merkel cells are a significant component of the somatosensory system in all mammals, and in all cases they are the anatomical substrate of a SA mechanoreceptor with somewhat different SA properties than Ruffini terminals. Merkel terminals are usually designated as a Type I SA unit and Ruffini terminals are Type II SA units as reviewed by IGGO (1974). Armed with the knowledge that Merkel terminals were SA units (IGGO and MUIR, 1969), CHAMBERs et al. (1972) provided physiological evidence for a second type of SA unit and included a drawing of a presumptive Ruffini corpuscle based on RUFFInI's own personal reports. As noted above, the present authors (BIEMESDERFER et al. 1978) were able to correlate CHAMBERS' report with the physiological and ultrastructural characteristics of a verified SA unit. However, we were not able to verify the physiological definition of a SA Type II unit provided by Chambers et al. (1972). Our technics at that time were different than those used by the Edinburgh group, and we still are somewhat cautious in the characterization of Type I and Type II SA units. We had a similar difficulty in our analysis of raccoon skin in that the criteria for identifying Type I and Type II SA units could not be adequately established (PUBOLS et al., 1971). The above is only of importance in characterizing the axons associated with Merkel cells as SA units. There is no disagreement on the conclusion that Merkel terminals are SA units.

What are Merkel cells? What do they do? Why are they important? We only have clues to the latter two questions, but the first can be answered with some firmness. Merkel cells are cells present near the basal layer of the epidermis or in the external root sheath of the hair follicle that have a convoluted nucleus and contain numerous cytoplasmic granules of approximately $150 \mathrm{~nm}$ in diameter that resemble secretory granules of protein-secreting endocrine cells (MuN. GER, 1965) (Figs. 7, 8). The secretory granules are polarized toward a sensory axon and are present on the opposite side of the cell from the Golgi apparatus where prosecretory granules can be identified. Since the Golgi is the site of membrane encapsulation of secretory granules and thus the site of prosecretory granules (MUNGER, 1958a, b), this polarization of the cell is even more unusual. The cell always has desmosomes with its adjoining keratinocytes; MUNGER (1965) used this fact to argue that these cells are 


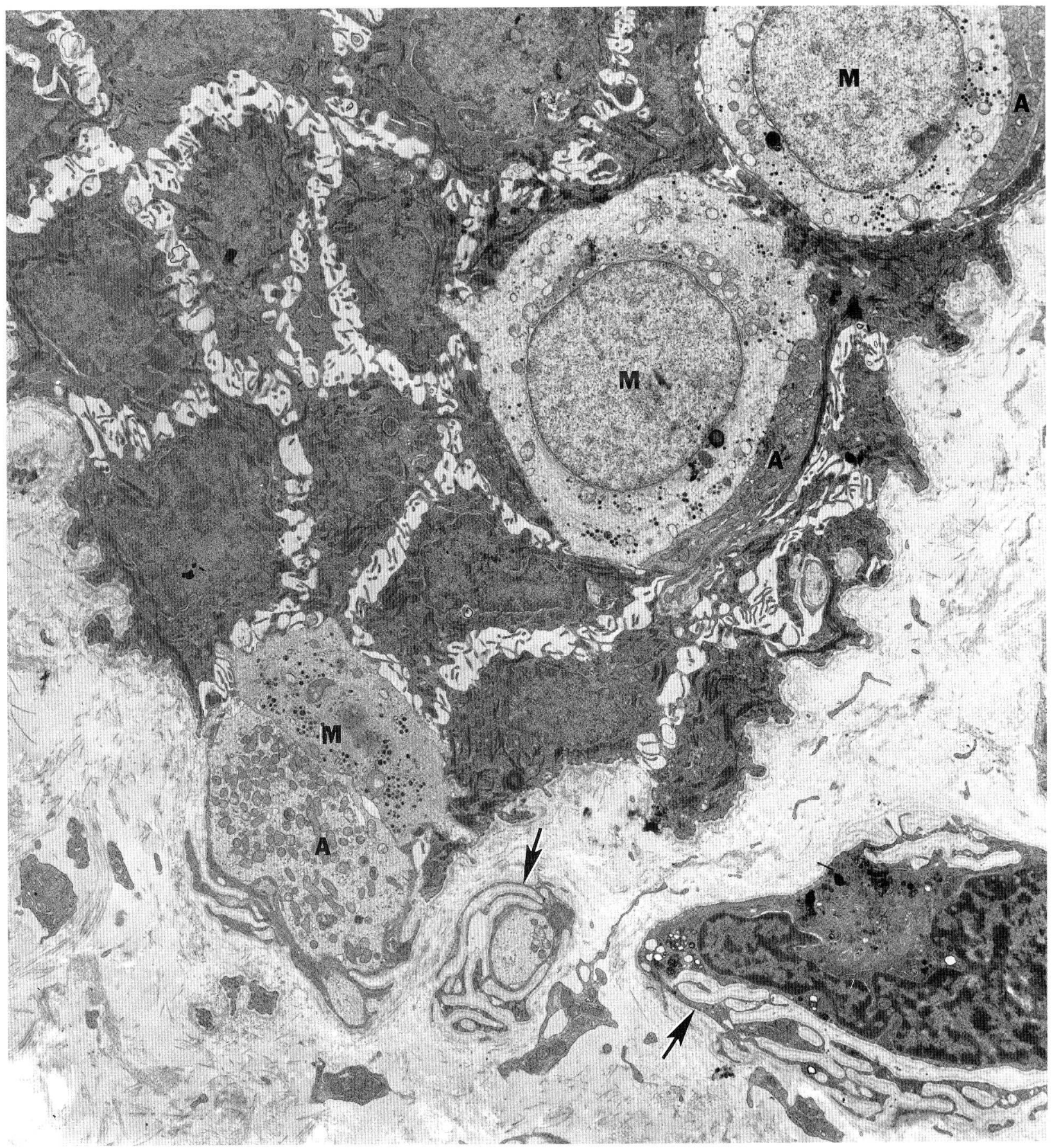

Fig. 7. Human glabrous digital skin, re-innervated Merkel cells. The human tissue is from the study of DELLON and Munger (1983) that dealt with the re-innervation of glabrous skin following traumatic nerve section. The cluster of Merkel cells $(M)$ and associated axons $(A)$ are present in the base of a papillary ridge. The Merkel cells are somewhat degranulated in comparison to the normal state. An abnormal lamellar cell is present to the bottom lacking any sign of innervation but an axon and surrounding lamellae (arrows) are also present. Lamellar cells would normally only be present high in the dermal papillae in the site of Meissner corpuscles. 


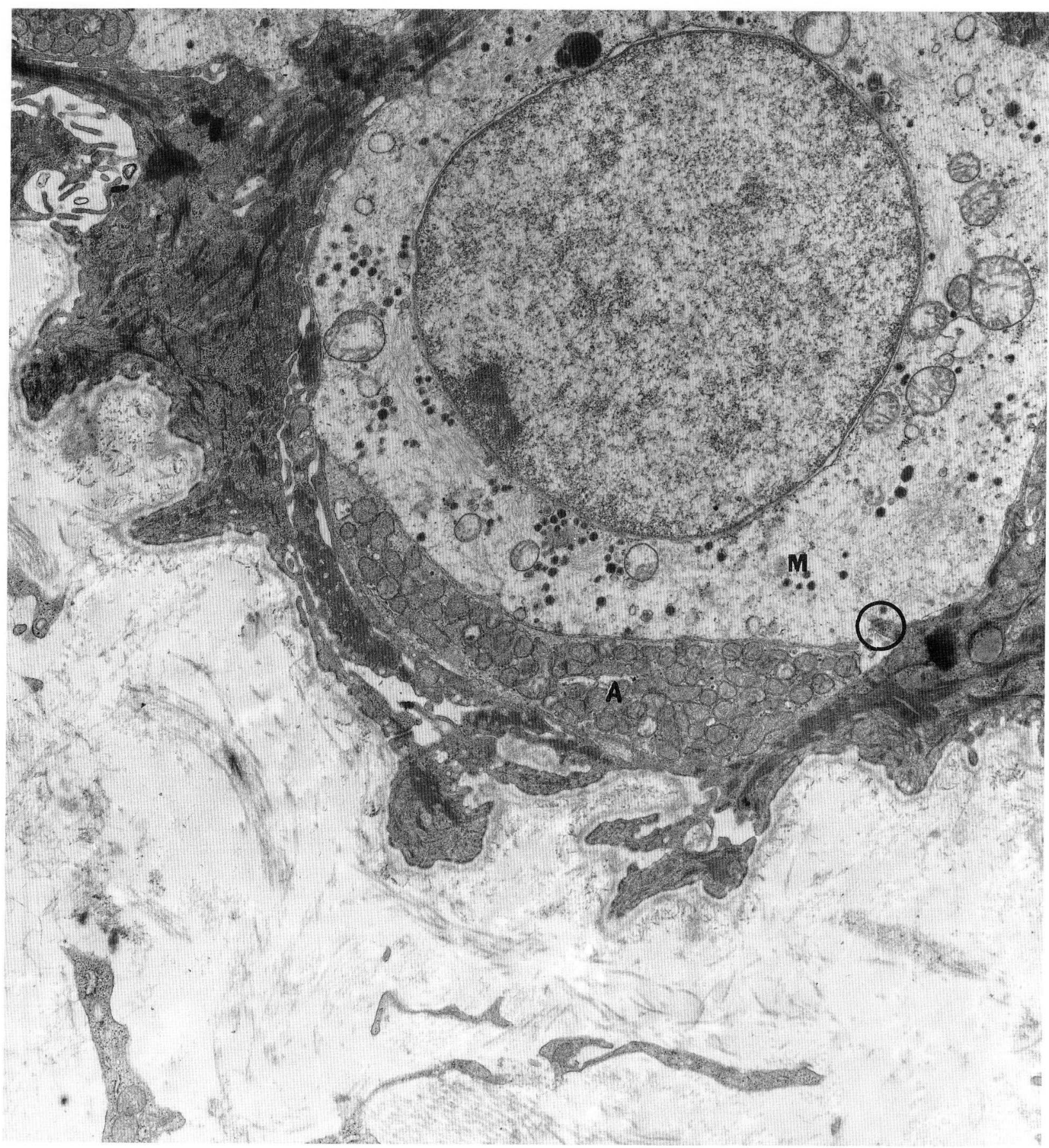

Fig. 8. Human glabrous digital skin, Merkel terminal. This micrograph illustrates at higher magnification a Merkel cell $(M)$ and associated axon $(A)$ from the section photographed in Figure 7 . The Merkel cell has secretory granules polarized toward axon. Scattered junctional complexes are present between the Merkel cell and surrounding keratinocytes (circle). The plasma membrane of the Merkel cell and the axolemma have suggestive areas of increased membrane density but lack convincing junctional complexes. $\times 15,000$ 
probably not "itinerants" in the epidermis as frequently expressed (HOLBROOK, 1983) and thus not of neural crest origin. The evidence favoring a neural crest origin is in our opinion not well founded. As noted below when considered developmentally the neural crest origin of Merkel cells is even more tenuous. The secretory granules can not be confused with melanosomes or granules of Langerhans' cells. Merkel cells have absolutely pathognomonic cytologic characteristics when studied by electron microscopy (Fig. 8).

The presence of desmosomes between Merkel cells and surrounding keratinocytes has been repeatedly demonstrated. Junctional complexes between the Merkel cell and associated axon are more tenuous. MUNGER (1965) did not observe membrane specializations in his original study but did in later studies on primate oral mucosa (MUNGER, 1975a, b) confirming ANDREs (1966) who observed small areas of increased membrane density in vibrissal Merkel cells. The function of such junctions is speculative (HARTSCHUH and WEIHE, 1980). In the Merkel cells of Figures 7 and 8 we may be seeing abnormalities related to the process of reinnervation and can not comment on the apparent absence of junctional complexes.

The statements regarding cytologic characteristics entail a subtle implication regarding identification. While presumptive Merkel cells can be identified in paraffin sections stained with silver (DELL and MUN . GER, 1986), we would have to agree with MERKEL (1880) that Merkel cells can only be absolutely identified in osmium fixed tissue. MERKEL (1880) clearly encountered a great deal of resistance to the concept that his Tastzellen were indeed a real entity as he could only demonstrate them in osmium-fixed tissue. Other contemporary neuroanatomists who used silver stains often failed to cite MERKEL's observations. The rediscovery of Merkel cells in electron micrographs by MUNGER (1965) was also greeted with some skepticism. The fact remains that to be absolutely sure, one must have electron microscopy to identify Merkel cells.

More recently Merkel cells have been charactrized immunocytochemically with antibodies recognizing cytokeratin proteins and surface N-cam markers (Moll et al., 1984, 1986; SAURAT et al., 1983, 1984 ; NESS et al., 1987). The problem with these studies is the fact that the number of Merkel cells identified immunocytochemically may not correspond with the number of Merkel cells seen by electron microscopy. In fact in the developmental studies of the present authors (BRESSLER and MUNGER, 1983; MUNGER, 1975a; Jones and Munger, 1985; Dell and Munger,
1986 ; MOORE and MUNGER, 1988) we have never, with one exception in unpublished material examined by Halata, seen a Merkel cell in the dermis. Moll et al. (1986) have described numerous Merkel cells in the dermis of human embryos. The stage of the embryo may be critical as MUNGER's studies have all been earlier than described by Moll et al. (1986). Clearly, the improved technique using immunocytochemistry will be important to define Merkel cells in the future.

Merkel cells have also been shown to contain metenkephalin (HARTSCHUH et al., 1978; GoTTSCHALDT and VAHLE-HINZ, 1982), vasoactive intestinal polypeptide (VIP) (HARTschuH et al., 1983) as well as neuron-specific enolase (Gu et al., 1981). The quinacrine fluorescence as described by CROWE and WHITEAR (1978) is consistent with a cytoplasmic content of ATP. All of these findings suggest a neural link and KUROSUMI (1976) has considered the possibility that they are in fact paraneurons as defined by FuJiTA (1977). NuRSE and DiAmOND (1984) have used the quinacrine fluorescence method to follow the development of Merkel cells in the rat. SMITH and CREECH (1967) applied a large series of neurotransmitters and ionically varied the environment of touch domes and failed to find any consistent response. The response of the receptors was blocked by nicotine, lobeline, various alkaloids and changes in cations. None of the above clarifies the functional role of Merkel cells. Functionally Merkel cells remain an enigma just as they were over 20 years ago (MUNGER, 1965).

One unusual occurrence of Merkel cells is in the human glans penis (HALATA and MUNGER, 1986). Merkel cells were seen in the dermis associated with genital end bulbs, but only most rarely. In this system the Merkel cells were innervated, but they lacked junctional complexes with other epithelial cells typically present in epidermal Merkel cells. The present authors have no rational explanation for the presence of a few dermal Merkel cells in the glans penis of one human subject.

Merkel cells are also a component of some large human hairs as described by HALATA and Munger (1984) in human eyelashes. As described by HorsT . MANN (1957), the external root sheath of large human guard hairs is not a uniform cylinder, but the external root sheath on each side of the encircling ring of sensory innervation has a protrusion into the connective tissue forming a collar that either projects down over the cluster of sensory nerves or upwards from below over the ring of sensory nerves. He thus termed these external root sheath (ERS) collars as "hanging down or standing up" depending on orienta- 
tion. Halata and Munger (1984) were not expecting to find Merkel cells in human hairs, but they were consistently observed in these collars of the ERS and identified in their study by both light and electron microscopy. Most of the Merkel cells observed by electron microscopy were not associated with identifiable axons, but axons could be seen innervating the cells of the ERS collars (presumptive Merkel cells?) in silver-stained preparations by light microscopy. The present authors in ongoing studies of hairs from other animals have not observed ERS collars or Merkel cells in the hairs from other animals. Halata and MUNGER (1980b) also failed to find Merkel cells in monkey eyelashes even though small ERS collars are present on monkey eyelashes. As noted below, Merkel cells are a prominent component in vibrissae of all animals with man being the exception in lacking vibrissae. The presence of Merkel cells in some human large guard hairs could be a phylogenetic remnant, but may mean that two types of SA units may be present in some human hairs. Further study of the physiology and cytology of hairy skin is clearly indicated.

Merkel cells are affected by their afferent nerves as denervation causes regressive changes (TACHIBANA et al., 1982, 1983). ENGLISH et al. (1983) provided a clear study documenting a loss of Merkel cells upon denervation. NURSE et al. (1984a, b) as well as RENEHAN and MUNGER (1986b) completely confirm the study by ENGLISH et al. (1983). Other reports have appeared claiming that Merkel cells do not change with denervation and should be ignored. As noted in the second study of NURSE et al. (1984b) they even increase in number with reinnervation. RENEHAN and MUNGER (1986b) did not find an increase to normal levels and it is important to note that with reinnervation the number of innervated Merkel cells is reduced.

The clearest example that may suggest a function for Merkel cells is their precocious presence during development (OchiaI and SUZUKI 1981). The first suggestion of a major role in development was presented by DELL and MUNGER (1986) in their study of monkey glabrous skin. As noted by JONES and MUN . GER (1985) innervated Merkel cells are present in the newborn opossum snout as well as glabrous skin of the hand contradicting published accounts (BRENO. WITZ et al., 1983). A grid of Merkel cells and sensory axons are present before papillary ridges begin to form, and ridges first form at 10 weeks and continue to differentiate for the next 4-6 weeks in human embryos (MOORE and MUNGER, 1988). All of the above studies concluded that sensory nerves and Merkel cells could have a profound role in the formation of papillary ridges and thus the fingerprint. Based on this concept, JONES and MUNGER (1987) produced lesions of the neural tube and were able to observe altered differentiation of hairy skin including precocious formation of hairs as well as hyperinnervation of dermis and epidermis with associated hyperplastic response of the epidermis. In glabrous skin the nerves and associated Merkel cells would thus appear to have a role in guiding the spatial and temporal sequences of differentiation as proposed by MUNGER and RICE (1986). All cutaneous derivatives differentiate in precise topological patterns including vibrissae, pelage, and papillary ridges (HALE, 1952; BABLER, 1978). Thus the concept of successive waves of neural and cutaneous differentiation is a biological generalization of considerable importance. The fingerprint begins to form in the distal pad and the progression is next to the palm, then filling in in a distal-proximal gradient as described by HALE (1952) and BABLER (1978) and confirmed by DELL and MUNGER (1986) and MOORE and MUNGER (1988).

\section{CORPUSCULAR RECEPTORS}

Sensory corpuscles are classically regarded as encapsulated but as noted by MUNGER (1971) many sensory corpouscles are incompletely encapsulated when examined at an ultrastructural level. The best example of an encapsulated corpuscle is the well known Pacinian corpuscle. That and Meissner corpuscles constitute two types of corpuscles that can easily be defined in mammalian skin. Both appear to be segregated from the general connective tissue compartment of the skin or deep dermis and we consider the degree of encapsulation as a minor point.

\section{Pacinian corpuscles}

Pacinian corpuscles are the largest sensory corpuscles to be found in the mammalian body. They are ellipsoidal in shape measuring almost $1 \mathrm{~mm}$ in length. Pacinian corpuscles are usually found in the palmar and plantar aponeurosis or genitalia deep to the skin and they are also present in ligaments and joint capsules. The most frequently studied source of these receptors is the mesentery of the cat intestine where they can be visualized by the naked eye. Pacinian corpuscles were first described by VATER in 1741 and rediscovered by PACINI almost 100 years later in 1840 . These receptors have been a frequently studied sensory receptor and light microscopic studies have been reveiwed by CAUna and MANNAN (1959) POLÁČEK 


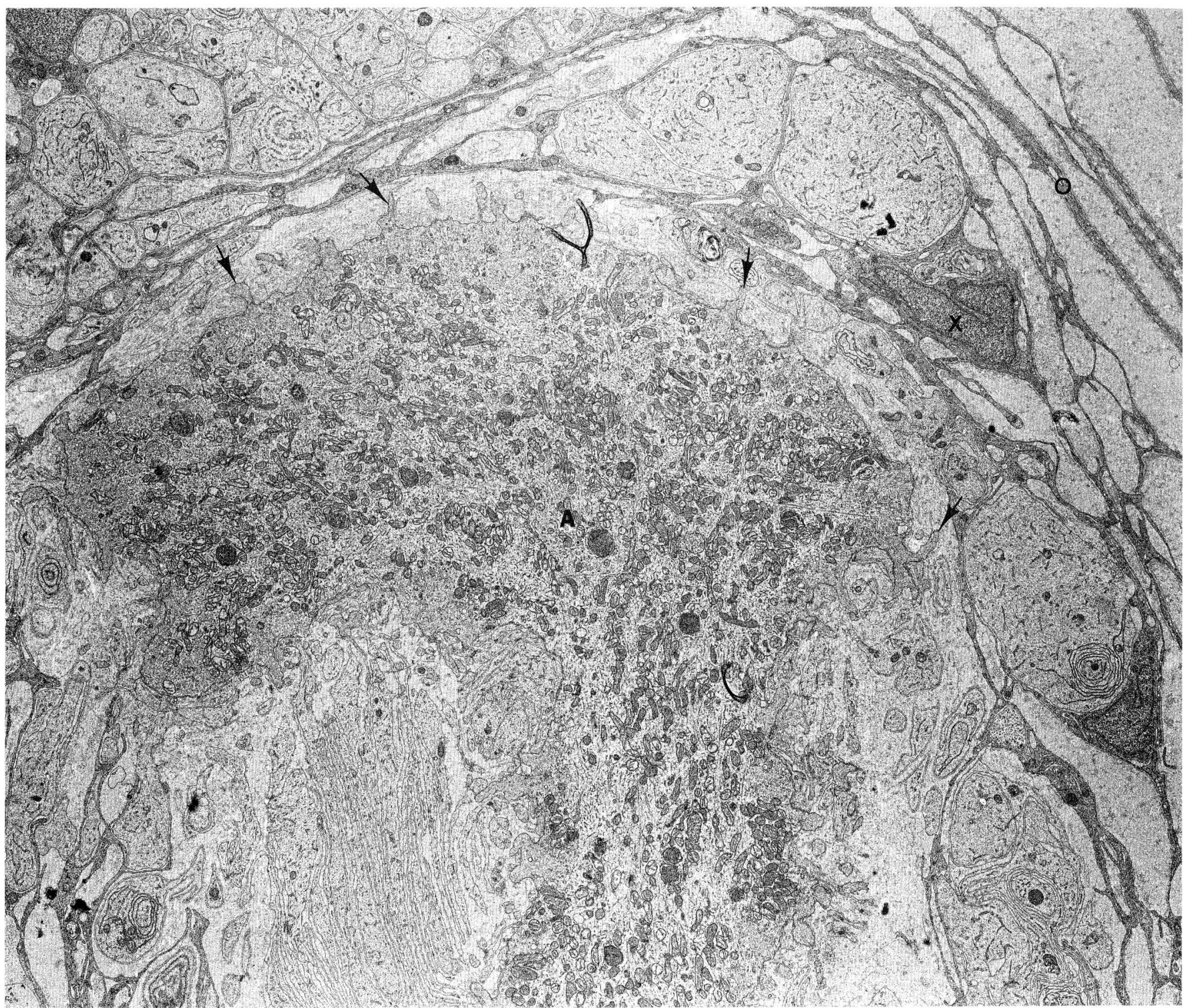

Fig. 9. Cat Pacinian corpuscle, the extreme tip of the axon. The axon terminal $(A)$ is enlarged as compared to sections more proximal and has numerous axonal spines (arrows) projecting into a connective tissue-like compartment that contains basal lamina-like material. The large pale cytoplasmic processes are the terminal ends of inner core cells, and these processes extend into a network of cellular processes of intermediate layer cells $(X)$ and outer core cells $(O)$. This micrograph is to be published in Cell Tiss. Res. 1988 and is published with permission of the publisher. $\times 4,900$

and Manazec (1966), and Chouchkov $(1971,1978)$. At a light microscopic level Pacinian corpuscles are distinctive and have two internal compartments surrounded by a dense capsule. The two internal compartments are referred to as the inner and outer cores. The axon is usually single and is present in the center of the inner core. A relatively large myelinated axon (A beta) typically enters one pole of the ellipsoid and the myelin sheath abruptly disappears to be replaced by the cellular processes of the inner core (Quillium and Sato, 1955). The unmyelinated portion of the axon in the inner core is usually relatively straight and terminates in an expanded tip.

At an ultrastructural level many mechanoreceptors have some features in common with those of Pacinian corpuscles and similarities will be pointed out as we deal with the other corpuscular receptors. Dating from the initial electron microscopic study of PEASE and QUILLIUM (1957), numerous investigators have reported on aspects of the cytology of these 


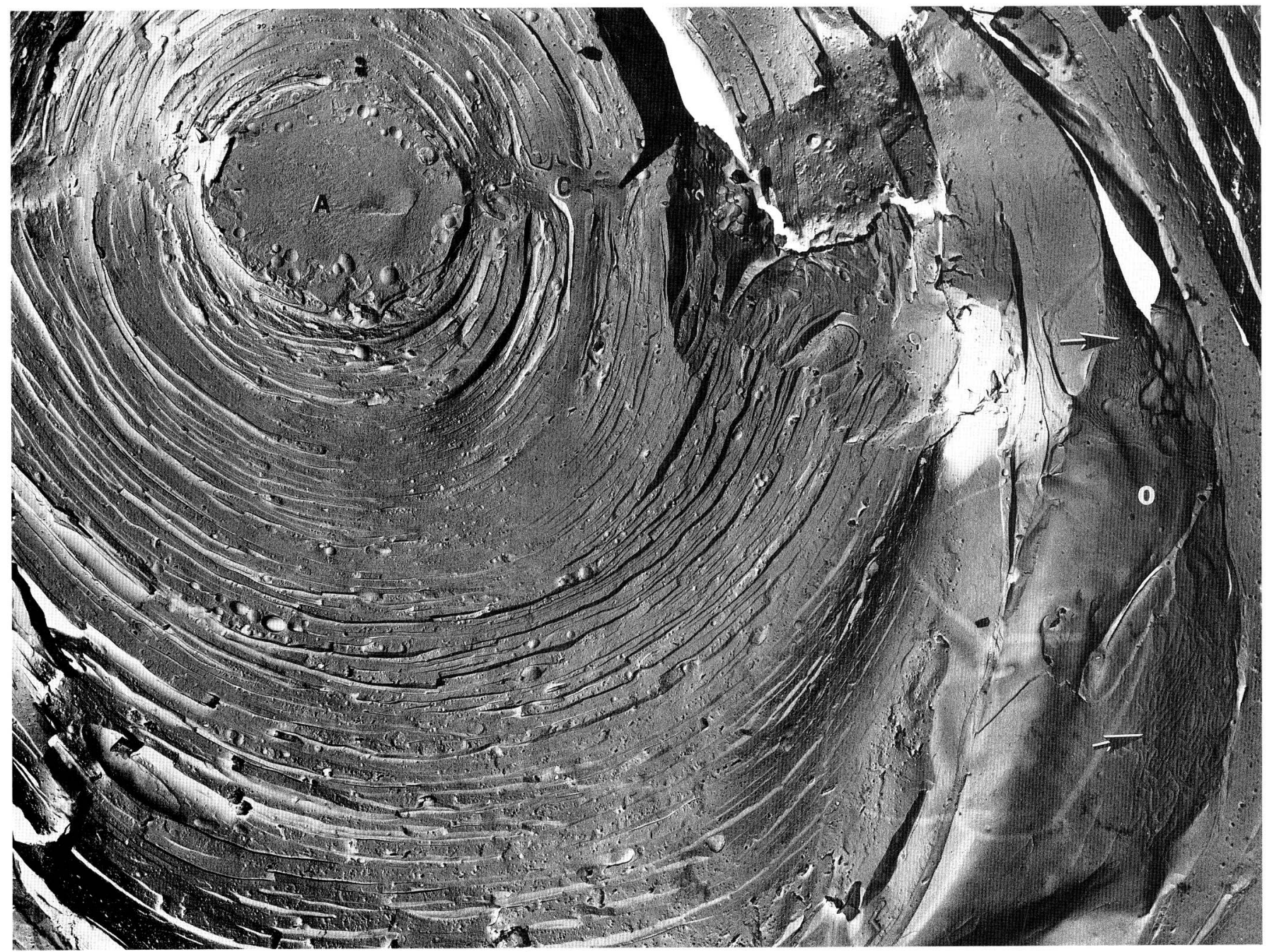

Fig. 10. Cat Pacinian corpuscle, freeze-fracture, preparation. The axon terminal $(A)$ is in the center of the inner core formed by the consecutive stacked lamellae. Rows of tight junctions (arrows) are characteristic of the innermost layer of the outer core. The cleft $(C)$ of the inner core connects the axon to the outer core $(O)$. This micrograph is to be published in J. Neurocytol. 1988 and is published with the permission of the publisher. $\times 5,000$

receptors (POLÁČEK and MAZANEC, 1966; Nishi et al., 1969; CHOUChKov, 1971; Munger, 1971; SPENCER and Schaumburg, 1973; Halata, 1975). The present description is based on the above studies as well as a recent series of our own papers re-evaluating the cytology of cat Pacinian corpuscles (MUNGER et al., 1988; IDE et al., 1988). The inner core is formed by thin cytoplasmic processes or lamellae formed from the so-called lamellar cells of the inner core (MUN GER, 1971). On occasion these lamellae branch and the cells can be traced for considerable distance up to half a mm (Munger et al., 1988). The lamellae are stacked closely on one another separated by thin connective tissue compartments containing extremely thin collagen fibrils. The lamellae do not complete- ly encircle the axon but rather consist of two bilaterally symmetrical halves with a cleft dividing the inner core into two halves. The axon is shaped like a flattened cylinder, as are the lanceolate terminals of hairs noted above. The lamellae tightly abut the short or $\mathrm{X}$-axis and the $\mathrm{Y}$-axis lacks investing lamellae, again reminiscent of lanceolate terminals.

The axon terminal contains numerous neurofilaments in the center of the axon and scattered microtubules. Mitochondria are frequently clustered just below the axolemma. Small protrusions of axoplasm referred to as axonal spines are present on the $Y$-axis face of the axon, again resembling lanceolate terminals. Axonal spines are always present facing both clefts and are especially numerous at the 
extreme tip (IDE et al., 1988) (Fig. 9). Axonal spines had previously been referred to as microspikes by SPENCER and SCHAUMBURG (1973).

The outer core consists of thin cells that concentrically completely encircle the inner core and each cell layer is separated by a connective tissue compartment. The connective tissue compartment contains scattered collagen fibrils and ground substance. The entire corpuscle is felt to be turgid when dissected free from the mesentery implying that the outer core is under some tension by the capsule.

While this basic pattern of organization has been recognized for many years, our concept of the form and function of Pacinian corpuscles has been somewhat altered by the recent freeze-fracture study of IDE and HAYASHI (1988) (Figs. 10, 11). This study prompted our joint cytological analysis of these receptors (MunGer, et al., 1988; IDE et al., 1988). The inner core is remarkable in having numerous gap junctions between lamellae. We could find numerous examples by conventional TEM that would be consistent with the identification of gap junctions. The gap junctions were limited to each hemi-inner core, that is to lamellae of only each half (Fig. 11). Since gap junctions are the cellular basis for low-resistance junctions between cells (LOEWENSTEIN et al., 1978), we could conclude that the halves are separately electrotonically coupled. MUNGER and IDE (1987) have proposed that the halves of the inner core could be both a sink or a source for $\mathrm{K}^{+}$necessary for the rapid adapting properties of the receptor.

The inner layers of the outer lamellae, in contrast, are coupled with tight junctions as identified in freeze-fracture preparations (IDE and HAYASHI, 1988) (Fig. 10). Tight junctions function to establish barriers in epithelial systems and would thus prevent ionic flow from inner to outer cores. In this regard we suggest that the outer core is merely an expanded perineurial compartment and the inner core is an expanded endoneurial compartment. The capsule is clearly continuous with the perineurium of the nerve trunk innervating the corpuscle (SHANTHAVEERAPPA and Bourne, 1963; ZelenÁ, 1984a). The cellular organization thus would restrict any flow of ions and current from the inner to outer compartment, but the ionic composition of the inner core is not known. ILYINSKY et al. (1976) have provided intriguing data suggesting a high $\left[\mathrm{K}^{+}\right]$in Pacinian corpuscles, but the data suggest that he was examining the outer core. The differences between inner and outer cores is also suggested by the fact that blood vessels, and macrophages are also present between the outer core lamellae (IDE and ToHYAMA, 1985). A further distinc- tion is the fact that the outer lamellae have a thin layer of basal lamina on both sides of the cells. The inner core lamellae lack any sign of a basal lamina except for those located in the periphery of the inner core.

A distinctive cell layer separates the inner from the outer cores that has been called the intermediate layer (IDE and HAYASHI, 1988). Cells forming the intermediate layer are irregular and branched forming a double or sometimes triple layer of relatively thin cell processes. The cytoplasm is relatively electron dense and the cells lack a basal lamina. Both of these features are typical characteristics of endoneurial fibroblasts (CHOUCHKOV, 1978). We propose that the intermediate layer cells are in fact modified endoneurial fibroblasts perhaps playing a role in the formation of the connective tissue components of the inner core.

The axolemma is considered to be the site of mechano-electric transduction (LOEWENSTEIN, 1971). The axolemma is more electron opaque as compared to the plasma membranes of the lamellar cells. In freeze-fracture preparations the axolemma has been noted to have differences in the distribution of intramembranous particles (IMPs) in the X and Y-axes (IDE and HAYASHI, 1988). The form of the axolemma of the $\mathrm{X}$-axis differs markedly from that of the $\mathrm{Y}$-axis. The $\mathrm{X}$-axis faces lamellae that tightly abut the axolemma and the $\mathrm{Y}$-axis has numerous axonal spines that project into the connective tissue compartment of the cleft.

In functional terms, Pacinian corpuscles are exquisitely sensitive RA mechanoreceptors that can signal the onset or cessation of compression or vibration transmitted to the body. When stimulated with a vibrating probe, the maximal sensitvity is approximately $300 \mathrm{~Hz}$ (BOLANOWSKI, 1984; KANDEL and SCHWARTZ, 1985). In an analogy to auditory receptors this means that the tuning curve has a maximal sensitivity at $300 \mathrm{~Hz}$. As we will note below, Meissner corpuscles can not be driven by frequencies above 100 $\mathrm{Hz}$. The RA properties of the receptor are thought to be due to the outer core, since surgical removal of some of the outer core changed the adaptive properties of isolated corpuscles (LOEWENSTEIN and SKALAK, 1966). Compression of the corpuscle will produce depolarization at the onset and hyperpolarization when the compression is removed (LOEWEN . STEIN, 1971; ILYINSKY, 1965). Corpuscles also evidence directional sensitivity; since when compression produces depolarization, rotation of the corpuscle 90 degrees will result in hyperpolarization upon compression. This remarkable anisotropy of the 


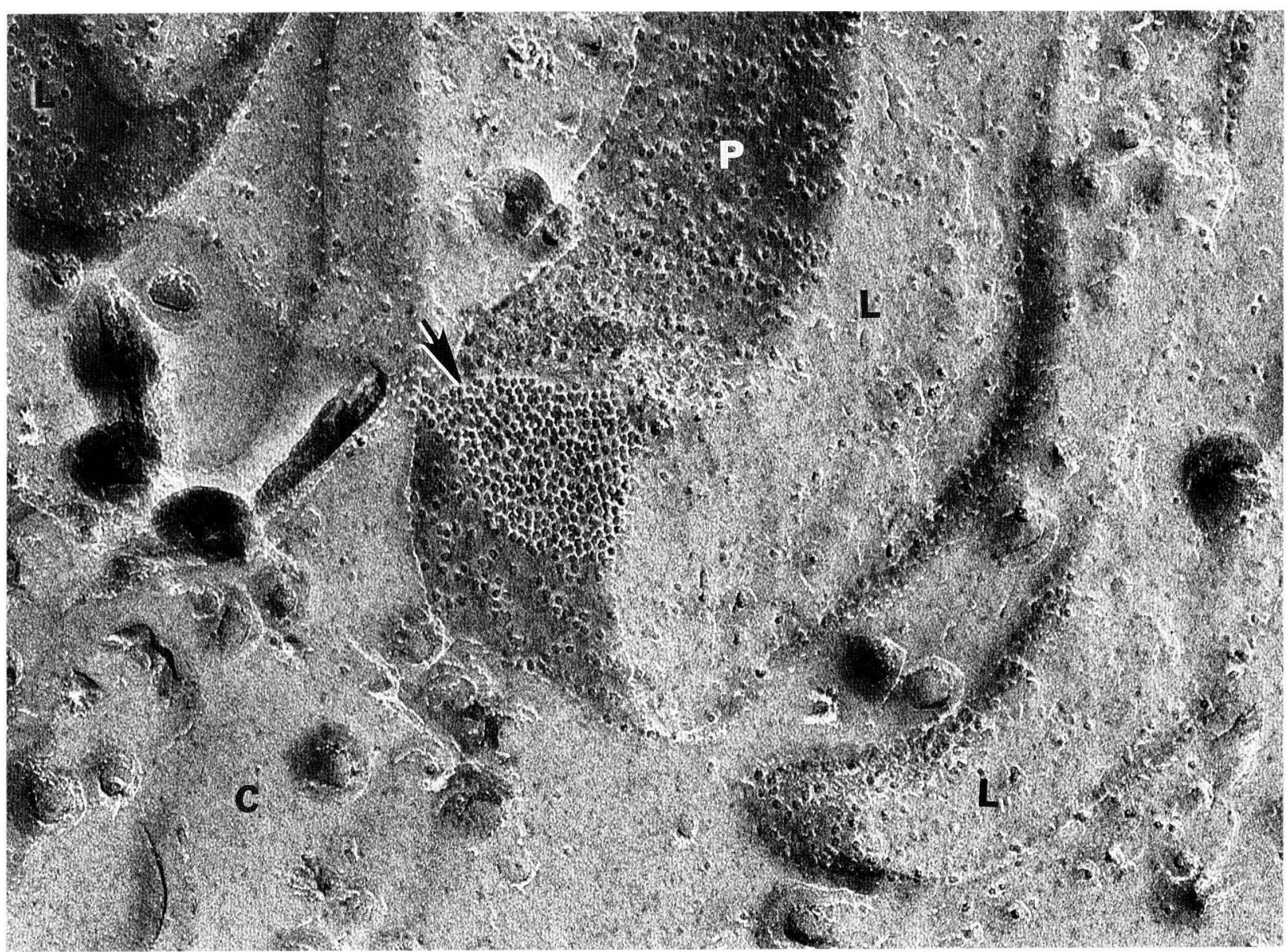

Fig. 11. Cat Pacinian corpuscle, freeze-fracture preparation. A gap junction is present on the tip of a lamella $(L)$ facing the inner core cleft $(C)$. Two other lamellae are present to each side of the central lamella. The P-face $(P)$ of the central lamella is labeled. This micrograph is to be published in J. Neurocytol. 1988 and published with the permission of the publisher. $\times 140,000$

response to mechanical deformation is analogous to the response of hair cells of the auditory system where deflection of the cilia in opposite directions produces hyerpolarization or depolarization (MUN. GER and IDE, 1987). This latter study reviews the physiological parameters of Pacinian corpuscles and correlates them with the structural anisotropy of the axon terminal in the inner core. Vibrations transmitted to the axon could result in differing strains at the level of the axolemma of the $\mathrm{X}$ and $\mathrm{Y}$-faces. Transduction of mechanical energy may be focused to the axonal spines of the $\mathrm{Y}$-axis due to the restriction of current flow at the $\mathrm{X}$-axis.

As is the case with Merkel terminals, the cellular elements of Pacinian corpuscles are trophically dependent on the sensory axon. ZeLENÁ (1980, 1981, 1984a, b) has provided convincing evidence that the inner core cells atrophy with denervation, and this response is more marked in younger animals (ZELENÁ, 1980). More remarkable is the effect of re-innervation, where her studies documented the presence of multiple axons in re-innervated corpuscles with small inner cores. When denervated in the adult, the corpuscles do not disappear but remain identifiable for long periods of time (ZELENÁ, 1984a). IDE (1987) has followed the regeneration of frozen corpuscles and some regeneration of the inner core is possible in the acellular inner core matrix with small lamellar cells (Fig. 12). The cells differentiating as lamellar cells would be derived from Schwann cells that grew into the destroyed inner core.

Sprouting of the central axon in Pacinian corpuscles is apparently a normal phenomenon in human corpuscles as recently described by our joint study 


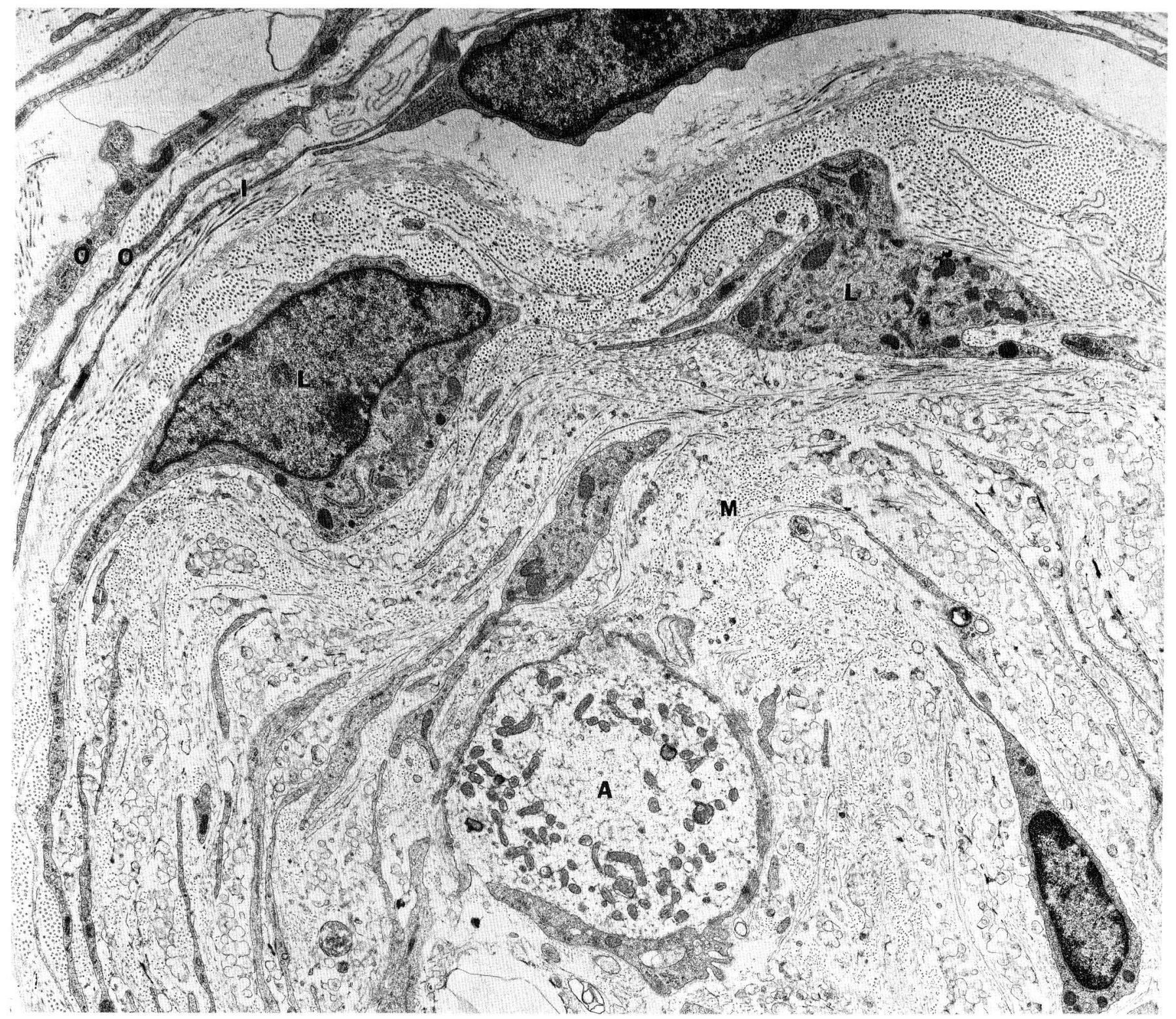

Fig. 12. Re-innervated cat Panician corpuscle. The acellular matrix $(M)$ of the corpuscle remains afer freezing. This tissue was removed 7 days after freezing. The regenerating axon $(A)$ is partly surrounded by processes of developing lamellar cells $(L)$ that are considered to be modified Schwann cells. These cells would have migrated in with the regenerating axon. Cells of the intermediate cell layer $(I)$ and outer core $(O)$ are present to the upper left. This micrograph was published previously in Brain Res. 1987, and is reprinted with the permission of the publisher. $\times 8,100$

(IDE et al., 1987). However, these corpuscles do not resemble those of regenerated axons as described by ZELENÁ (1984b). In normal human corpuscles (and opossum material in unpulished data of MUNGER) the central axon branches are present in a normal inner core, whereas with re-innervation each axon is thinly covered with a separate sheath of inner core cells. The architecture of the inner core is thus distinctive in re-innervated corpuscles. We have re-examined the human material used by DELLON and MUNGER (1983) and can confirm ZELENÁ's observations. The structure at a light microscopic level is distinctive, permitting the diagnosis of re-innervation in all cases. These observations would support the thesis that the inner core of Pacinian corpuscles is normally capable of providing a strong trophic influence on sensory 
nerves. Perhaps more importantly, this study conclusively proves the existence of sprouting of normal sensory axons in both man and a marsupial.

Pacinian corpuscles develop long after Merkel terminals and hair follicle receptors can be recognized as described by SAITo (1952), MrSEvic et al., (1969), MALinOVSKÝ and Sommerová (1972) and CAUNA and MANNAN (1959) by light microscopy and ZELENÁ (1978) by electron microscopy. The initial corpuscles can be recognized before birth, but the complement of inner core cells and completion of the outer cores occur postnatally. As described by ZELENÁ (1978), mesenchymal cells accumulate around axons and presumptive Schwann cells become arranged in rows along the axon. The presumptive Schwann cells differentiate into lamellar cells and extend cytoplasmic processes around the sensory terminal. Mesenchymal cells around the receptor develop into outer core lamellar cells.

The histochemical properties of Pacinian corpuscles have been documented in a series of papers at light and electron microscopic levels. These corpuscles contain intense non-specific cholinesterase (ChE) activity in the inner cores as described by HEBB and Hill (1955), LoEWENSTEIN and Molins (1958) and CAUnA (1960). Ultrastructural studies have demonstrated the localization of the enzyme to the periaxonal and interlamellar spaces (IDE and SAITO, 1980c) as well as the plasma membrase of lamellar cells (DubovÝ and MALINOVSKÝ, 1982; DuBOVÝ and ČERNÁ, 1987). Non-specific ChE activity is present in many mechanoreceptors with specialized Schwann cells such as Meissner, simple and Ruffini corpuscles in joint capsules (TOYOMA, 1985) and baroreceptors in the atrial wall (YоKOTA et al., 1983) and carotid sinus (YoKOTA et al., 1982). The functional significance of this enzyme is not understood at present.

\section{Meissner corpuscles}

Meissner corpuscles are present in the dermal papillae of glabrous skin of the palms, soles, and lip of primates, most marsupials and many rodents. Meissner corpuscles are absent in the genitalia as described by Halata and Munger (1986). The corpuscle is usually ovoid in shape with a long axis perpendicular to the skin surface and they measure 30-100 $\mu \mathrm{m}$ in length. These corpuscles typically tightly abut the basal surface of the epidermis. Meissner corpuscles were first described by WAGNER and MEISSNER in 1852 and the subject of a monograph by MEISSNER (1853) that is the basis for his name being associated with the receptor. As is the case of Pacinian corpus- cles, the other scholar involved in the recognition of the receptor has been forgotten with time. The initial studies involved the use of methylene blue (KRAUSE, 1859, 1881; DOGIEL, 1893, 1903) and more recent studies have relied on silver staining (CAUNA, 1956, 1958; Aiba, 1956; YAmAmoto et al., 1957 ; Seto, 1963). The older literature has been reviewed in detail by CAUna (1958). The corpuscle consists of axon terminals and associated non-neural cells referred to as lamellar cells analogous to those present in Pacinian corpuscles (MUNGER, 1971). The corpuscles are often encapsulated with cells resembling perineural cells but the encapsulation is often not complete. HALATA and Munger (1983) noted that the degree of encapsulation appeared to be correlated with the position of the corpuscles in primate lips. Those deeper in the dermis tended to have a more complete capsule.

The corpuscles were first studied by electron microscopy by PeAse and Pallie (1959) and CAuna and Ross (1960). Numerous reports on the fine structure of Meissner corpuscles were conducted during the succeeding decade (MUNGER, 1971, 1973, 1975a, b; HASHIMOTO, 1973; HalaTA, 1975; ChOUCHKOV, 1973a, b, 1978; CASTANO and Ventura, 1978, 1979). The common characteristic is the course of the axon that winds through the corpuscle in a manner reminiscent of ribbon candy with stacks of lamellae separating the axons branches (Fig. 13). Other corpuscles have different forms of terminal axonal specialization including Krause's end bulb, Golgi-Mazzoni corpuscles and genital end bulbs. The latter has already been reviewed in the section dealing with FNEs.

IDE (1976) has described the presence of Meissner corpuscles in rodent glabrous digital skin. This observation is important due to the frequent use of rodents as experimental animals in studies on the peripheral nervous system (WINKELMANN, 1960; TACHIBANA et al., 1987a, b). The receptor in mice is indeed smaller than primate corpuscles, but no smaller than marsupial Meissner corpuscles (MUNGER, unpublished observations). In mice, the axon terminal weaves back and forth between stacks of lamellae and the axon tends to be sandwiched between lamellae. These corpuscles differ from simple corpuscles described below and in our opinion are sufficiently similar to their primate and marsupial counterpart to be referred to as murine Meissner corpuscles.

The axon innervating Meissner corpuscles is typically single in most primates, but in man they are often doubly or multiply innervated as described by CAuna $(1956,1958)$. The lamellae are invested with basal lamina in this regards resembling the lanceolate receptors of hair follicles rather than the 


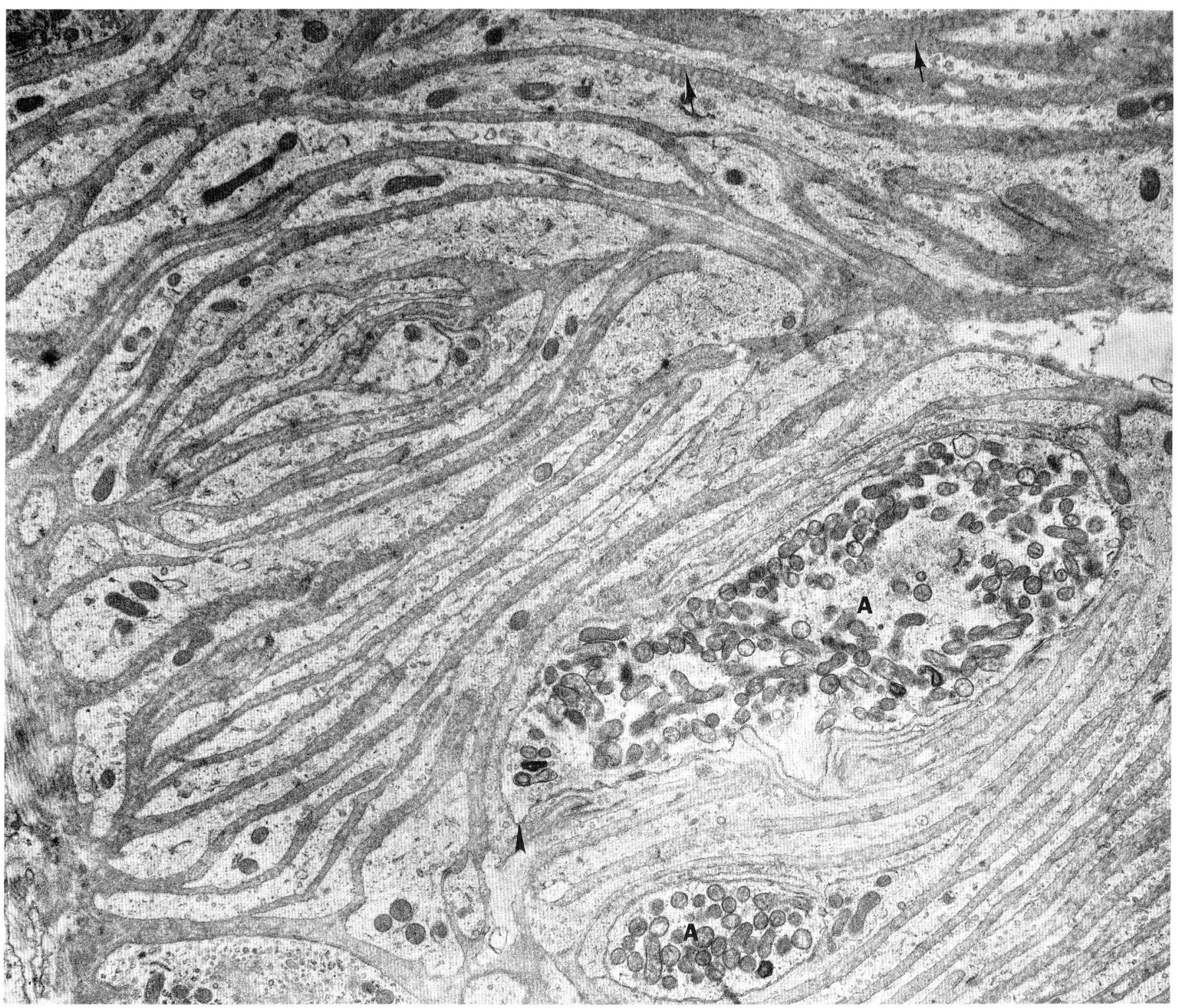

Fig. 13. Human Meissner corpuscle. The axon terminals $(A)$ contain abundant mitochondria. An axonal spine is indicated by the arrowhead, and near the arrowhead numerous vesicles are present in the axon. The stacked cytoplasmic processes are the lamellae of lamellar cells whose nuclei are out of the plane of section. The material between the lamellae is basal lamina and scattered collagen fibrils. Areas of matrix representing presumptive fibrous long-spacing collagen are indicated by the upper arrows. $\times 10,000$

inner core of Pacinian corpuscles. Mitochondria tend to be present in a subaxolemmal position with the center of the axon containing numerous neurofilaments. This arrangement is also similar to that of Pacinian corpuscles. Numerous vesicles resembling synaptic vesicles are present near the surface of the axon and in the expanded tip. Axonal spines resembling those of lanceolate and Pacinian corpuscles are typically present on the $\mathrm{Y}$-axis of the axon. The axonal spines contain numerous filaments and lack mitochondria.

The cell bodies of lamellar cells typically have a complete investment of basal lamina, while the lamellae themselves are focally devoid of basal lamina. The interlamellar spaces contain occasional collagen fibrils and other amorphous filamentous material. The lamellae themselves contain filaments and scattered mitochondria as well as numerous pinocytotic vesicles or caveolae. In general, the lamellar cells of Meissner and Pacinian corpuscles as well as the 


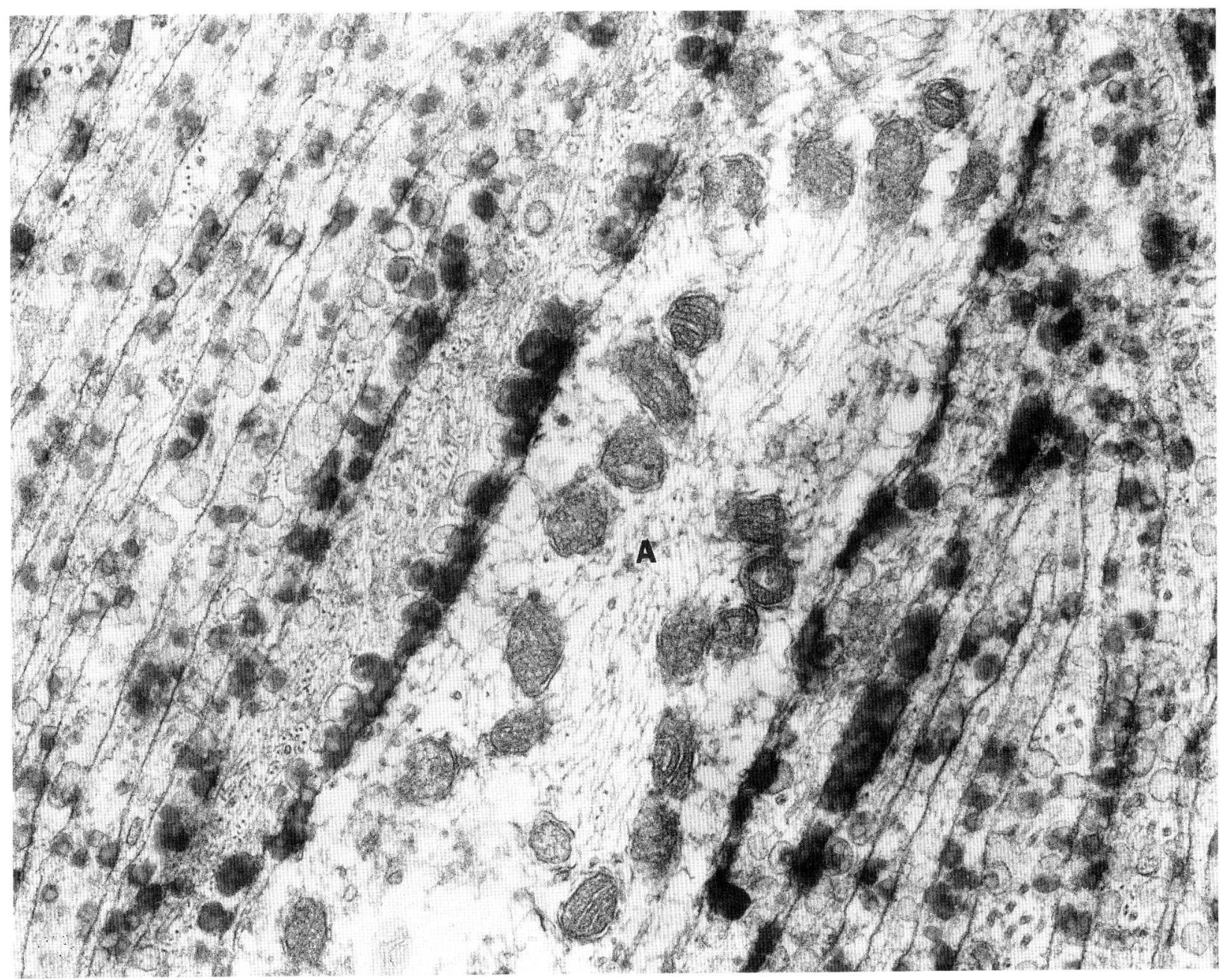

Fig. 14. Murine Meissner corpuscle demonstrating non-specific ChE activity. The electron opaque masses are the reaction products deposited in the interlamellar spaces and between the axon $(A)$ and the investing lamellae. Some reaction products are present within pinocytotic vesicles or caveolae. This micrograph was previously published in Acta Histochem. Cytochem 1980 and is reprinted with the permisson of the publisher. $\times 53,000$

specialized Schwann cells of lanceolate terminals are all remarkably similar.

At a physiological level, Meissner corpuscles are RA units with a maximal sensitivity in the range of $40 \mathrm{~Hz}$, well below that of Pacinian corpuscles. MER ZENICH and HARRINGTON (1969) used the term "flutter vibration" to describe the type of sensation perceived by Meissner corpuscles. As noted above in our discussion of Merkel terminals, in primate glabrous skin the sum of Merkel and Meissner terminals provides us with the ability to read braille (JOHNSON and LAMB, 1981) by forming the peripheral basis for parallel processing. Other corpuscular receptors may also be RA units, but most will have unique adaptive properties (SAKADA and AIDA, 1971a, b). Based on the similarities of the lamellae and axonal receptor of all
RA units considered so far, the conclusion is logical that the adaptive properties are most likely dictated by the relationship of the lamellae to the sensory axon.

The distribution of intramembranous particles has been reported by IDE et al., (1985) in murine Meissner corpuscles by freeze-fracture. The axonal plasmalemma has $10 \mathrm{~nm}$ particles at a density of $2,300 / \mu \mathrm{m}^{2}$ in the $\mathrm{P}$ face. The lamellar cell plasma membrane has approximately 3,300 particles $/ \mu \mathrm{m}^{2}$. The lamellae themselves have occasional gap junctions between adjacent lamellae again reminiscent of Pacinian corpuscles. The axonal membranes are consistently more electron opaque in conventional TEM preparations and YoshiDA et al., (1988) have documented similar findings in freeze-substitututed 


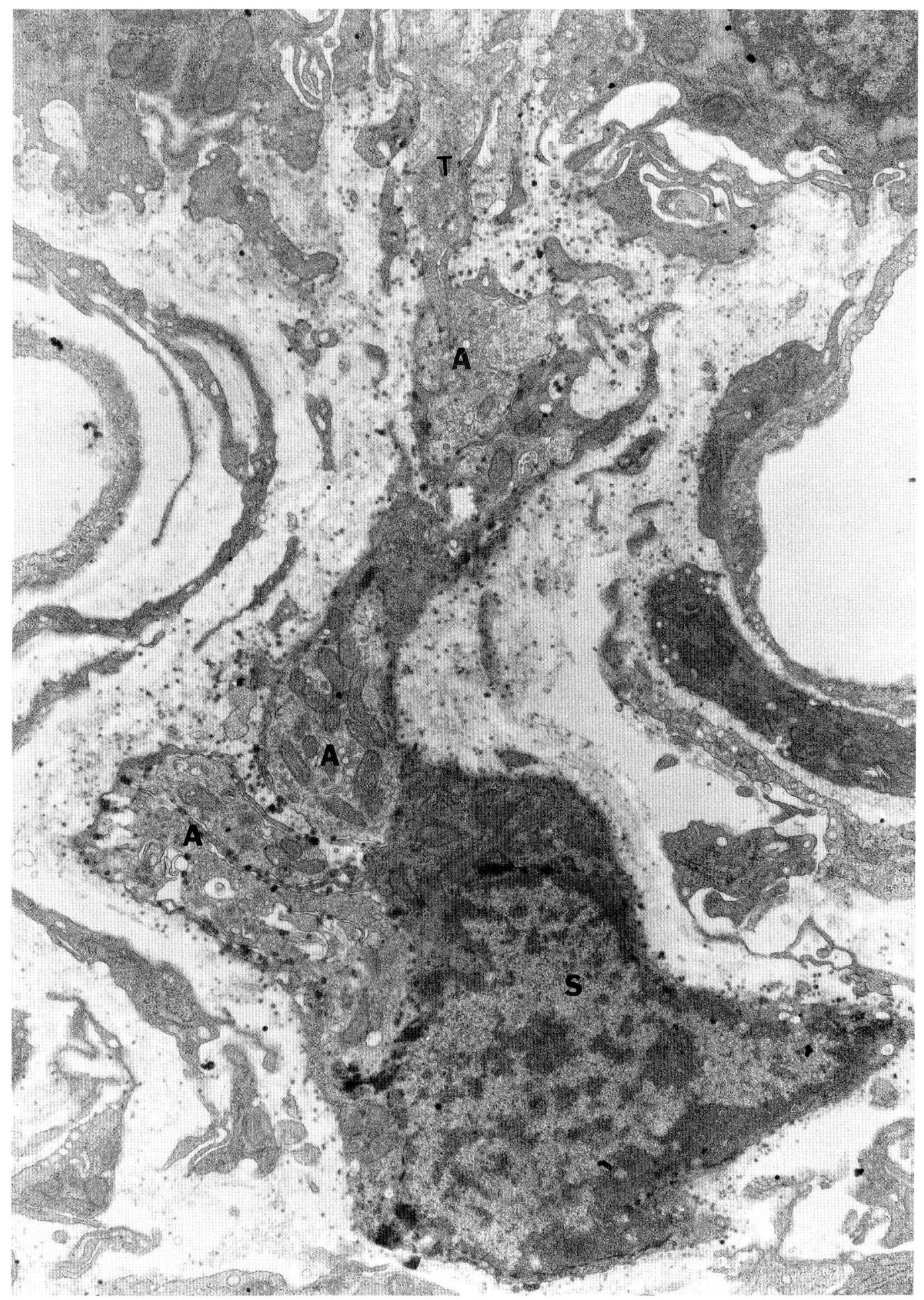

Fig. 15. Murine Meissner corpuscle, 5 day-old rat, reacted for $\mathrm{ChE}$. This micrograph demonstrates the initial stages of formation of Meissner corpuscle. The growing tip of an invading axon $(T)$ has entered the epidermis crossing through the basal lamina. The axonal profiles $(A)$ are enveloped by Schwann cell processes $(S)$ that will develop into lamellar cells. ChE activity is present in the interspaces between axons and Schwann cell processes, and within the nuclear envelope of Schwann cells. This micrograph was previously published in Arch. Histol. Jap. 1982 and is republshed with the permission of the publisher. $\times 15,000$ 
Meissner corpuscles. The membrane specializations may well be involved in the events of transduction.

The development of Meissner corpuscles has been studied by PoláčEK and Halata (1970), Munger (1975a), IDE (1977) and Halata (1981). Developing axons are typically intimately related to the epidermis prior to formation of the corpuscle, and in mice these events occur postnatally (IDE, 1977; HALATA, 1981) (Fig. 15). Some naked axons actually enter the epidermis and small axonal branches course between epidermal cells. Isolated growth cones at these early stages consistently lack a Schwann cell investment resembling the early innervation of the base of the papillary ridges (DELL and MUNGER, 1986). The immature Schwann cells have non-specific ChE and the differentiated lamellar cells retain this activity (IDE and SAITO, 1980b; IdE, 1982c) (Figs. 14, 15). These observations lend support to the concept that lamellar cells of mature Meissner corpuscles are modified Schwann cells (MUNGER, 1971).

Meissner corpuscles are trophically dependent on their sensory innervation just as Pacinian and Merkel terminals have been noted previously. The changes with denervation have been studied by DELLON (1976), DELLON et al., (1975), IDE (1982a, 1982b) and DELLON and MUNGer (1983) using human as well as experimental material. Following nerve transection, the axons are destroyed and the lamellae undergo atrophy. Regenerating axons will enter an empty corpuscle and in most cases will result in redifferentiation of the lamellar cells (IDE, 1982b, 1986, 1987), however, in some cases atrophic corpuscles can be identified after sensory nerve regeneration (SAMULACK et al., 1986). As is the case of re-innervation of Pacinian corpuscles, these observations stress the importance of trophic interactions between axons and lamellar cells.

The histochemical properties of Meissner corpuscles resembles other corpuscular receptors in displaying active non-specific ChE (WINKELMANN, 1960; CAUnA, 1960; IDE and SAITO, 1980b), alkaline phosphatase (IDE and SAITO, 1980a; DubOVY and MALINOVSKÝ, 1982) and carbonic anhydrase activity (ToHYAMA and IDE, 1987). Human and murine corpuscles demonstrate intense $\mathrm{ChE}$ activity in the interspaces between the lamellae, and in the periaxonal spaces between the lamellae and axon (IDE and SAITO, 1980b) (Fig. 14). No enzyme activity of the above examples is present in the axon itself. The ChE enzyme is synthesized by the lamellar cell since activity is present in the cisternae of the rough endoplasmic reticulum and nuclear envelope. The activity is abolished when the cells are killed by freezing (IDE, unpublished data).

The intense ATPase and alkaline phosphatase activities have only been described to date in murine Meissner corpuscles (IDE and SAITO, 1980a). These enzymes are localized on plasma membranes of lamellar cells. and axon terminals. Carbonic anhydrase activity on the other hand is present in the axons (TOHYAMA and IDE, 1987). The axons also contain S-100 protein, neurofilament proteins, and neuron-specific enolase (IwANAGA et al., 1982). The axons are known to take up foreign proteins such as horse-radish peroxidase (JIRMANOVÁ and ZELENÁ, 1980).

Age related changes of Meissner corpuscles in man have been described by CAUnA (1956). This study needs to be extended to include electron microscopic characterization of such changes. Reported changes with age include a reduction in the size and number of axons in the corpuscles as well as a reduction in size of the entire corpuscle. MATHEWSON and NAVA (1985) have reported on some age-related changes in murine Meissner corpuscles.

\section{Other corpuscular receptors}

Numerous other sensory corpuscles have been described in the literature based on light microscopic criteria alone (STÖHR, 1928; SETo, 1963, MUNGER, 1971; Halata, 1975). When electron microscopy is used in addition some of these corpuscles are found to be quite different than Meissner corpuscles as in the example cited under FNEs with respect to genital end bulbs (Halata and Munger, 1986). Subtle difference in the organization of the inner core, i. e., the axon and associated specialized cells, is the key to sorting out this complicated literature.

In contrast to the stacked lamellae of Meissner corpuscles, some corpuscular receptors have completely concentric lamellae resembling miniature Pacinian corpuscles (MUNGer and PUBOLS, 1972). HALATA and Munger (1983) have proposed that the terminology of POLÁČEK and HALATA (1970) should be used and such terminals be referred to as simple corpuscles (Fig. 16). Simple corpuscles can on occasion be somewhat coiled as in the case of the human penis (Halata and Munger, 1986 (Fig. 17)). Simple corpuscles using the criteria of concentric lamellae can be found in oral mucosa (SAKADA and AIDA, 1971a, b; MUNGER, 1975a, b; SPASSOVA, 1981; WATANABE and YAMADA, 1985; TACHIBANA et al., 1987a; TOYOSHIMA et al, 1987), vermillion border of the lip (Halata and Munger, 1983; Tachibana et al., 1987b) and genitalia (PATRIZI and MUNGER, 1965; 


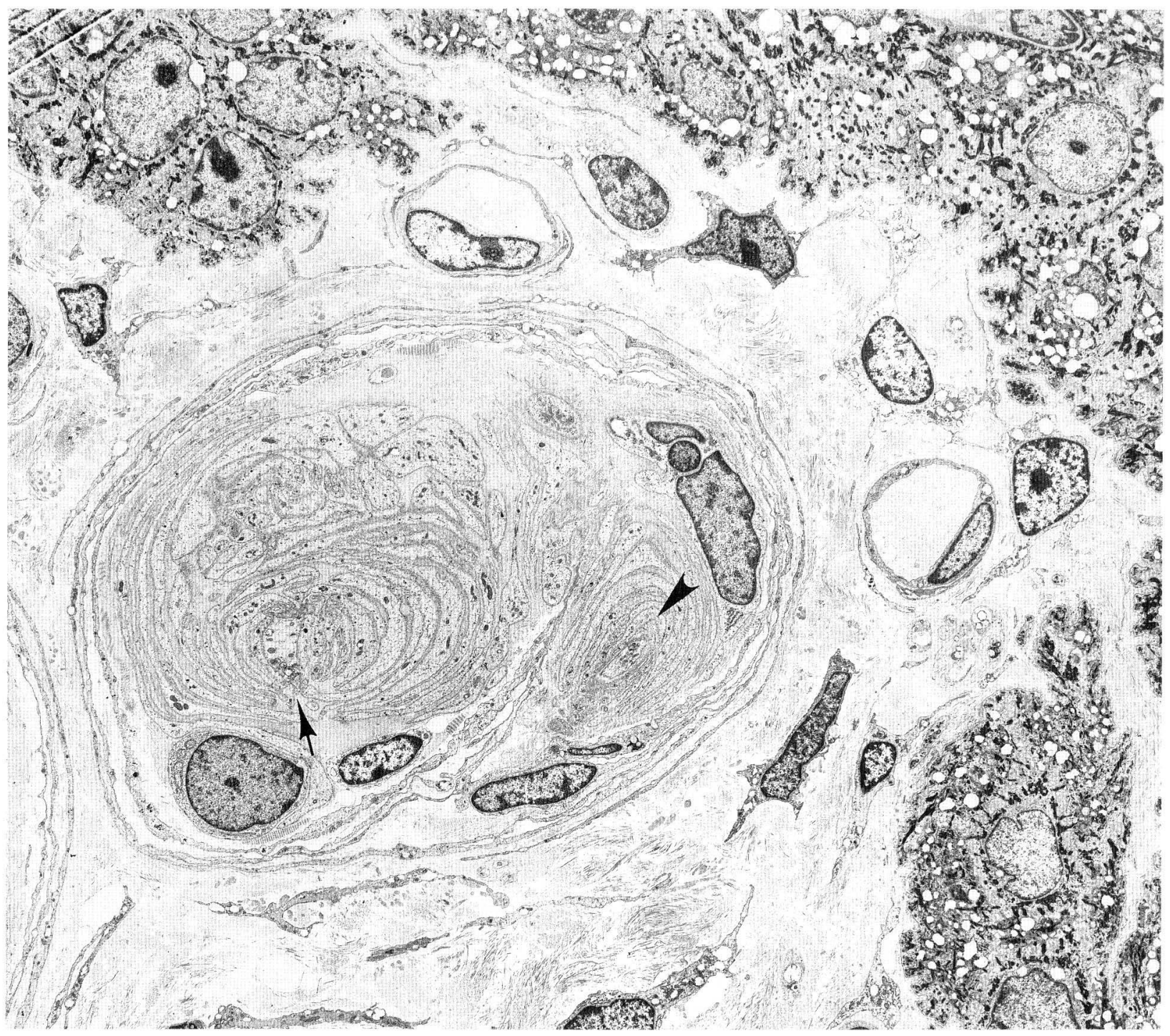

Fig. 16. Simple coiled corpuscle, monkey lip. This corpuscle has two axonal profiles. The arrow indicates a partial cleft in the inner core, but the arrowhead to the right illustrates a lamella that closes the cleft as in the example at higher magnification in Figure 17. The epidermis is present in the upper and right hand portion of the micrograph. This micrograph was kindly provided by $Z$. HALATA. $\times 2,000$

PoláčEK and MalinovskÝ, 1971; Halata and Mun GER, 1986) and facial skin (HALATA, 1972; SUZUKI and Kurosumi, 1972; HALATA and MUNGER, 1980b; STRASMANN et al., 1987) in a variety of mammals.

As noted previously, some corpuscular receptors have turned out to be a complex array of presumptive FNEs as in the case of genital end bulbs (Halata and Munger, 1986) (Fig. 2). Such terminals are also occasionally observed in oral mucosa as described by Chouchkov (1973c) and in larynx by NAGAI (1982).

Other corpuscular receptors defined by light micro- scopy (methylene blue or silver staining) include Krause's end bulb, Golgi-Mazzoni corpuscles and mucocutaneous end organs (WINKELMANN, 1960). KRAUSE (1859) described sensory corpuscles in the human conjunctiva with convoluted terminal axons. DOGIEL (1893) confirmed the identification of such corpuscles in genitalia. Based on our evaluation of the literature, true Krause's end bulbs are identical to those described by electron microscopy by $\mathrm{CHOUCH}$ KOV (1973c) in oral mucosa and HalatA and Munger (1986) in the human penis. Krause's end bulbs are clusters of FNEs. 


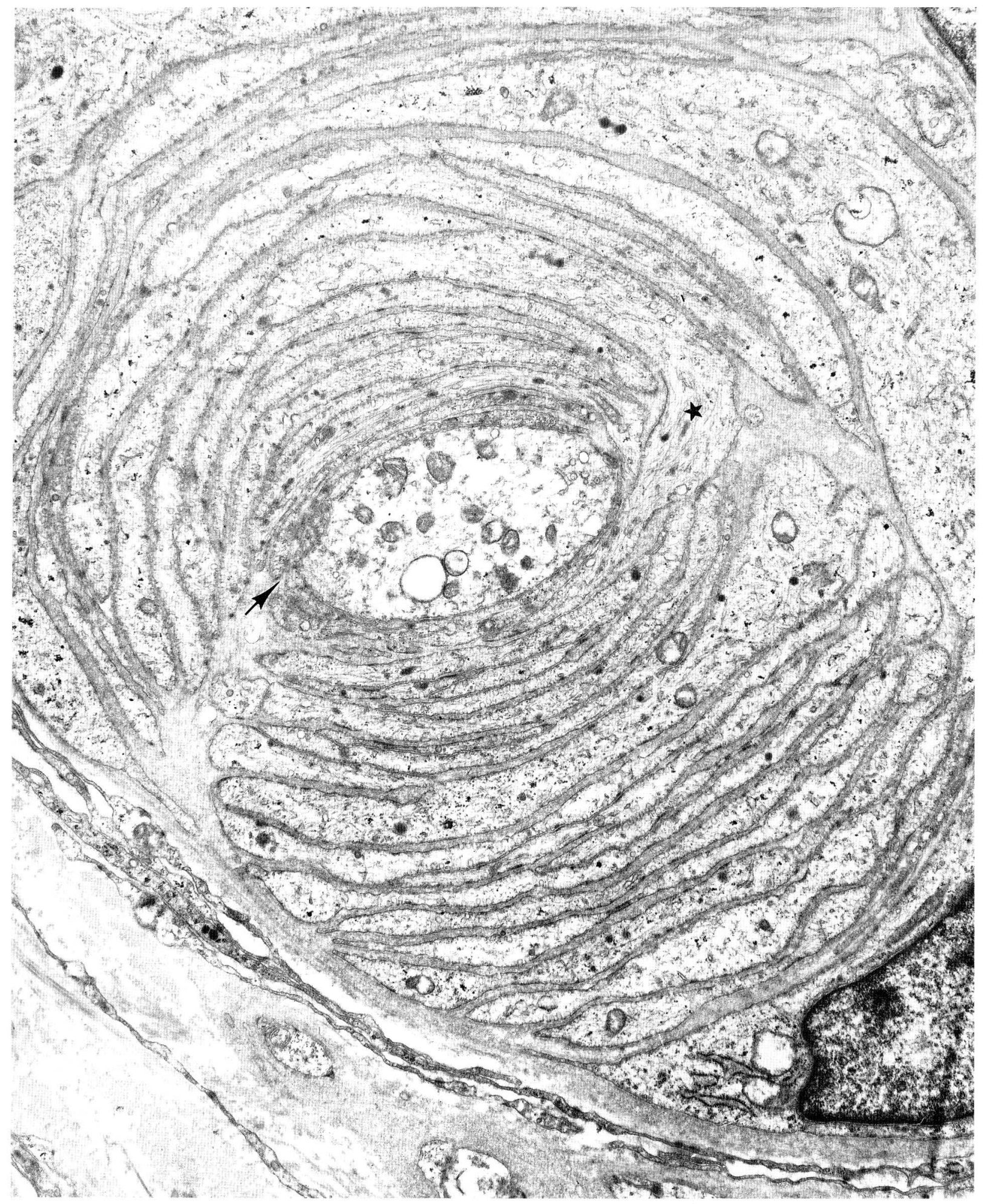

Fig. 17. Simple coiled corpuscle, monkey lip. The arrow indicates thin lamellae enclosing the central axon. Thus the cleft is only partial. The lamellae containing the star completely closes the partial cleft. While the numerous lamellae are reminiscent of Meissner corpuscles, the encircling lamellae are not. This micrograph was kindly provided by $Z$. HALATA. $\times 11,500$ 
Golgi-Mazzoni corpuscles are also difficult to identify using modern criteria. DoGIEL (1903) stated that Golgi-Mazzoni corpuscles were similar to Krause's end bulb. STÖHR (1928) considered Krause's end bulb, Dogiel's genital end bulb and Golgi-Mazzoni corpuscles to form a continuum, i. e., they were all variants of the same basic structure. While it is true that simple corpuscles have been called Golgi-Mazzoni corpuscles, we would propose that the descriptive term simple corpuscle or coiled simple corpuscle is preferable. When the axon terminal is in fact a FNE, we propose that the appropriate term would be corpuscular FNE.

\section{VIBRISSAE}

Vibrissae consist of a large hair follicle typically several times larger than guard hairs encased in erectile tissue that is in turn encased in a dense connective tissue capsule (RENEHAN and MUNGER 1986a; RICE et al., 1986). The blood sinus is of two portions, a lower cavernous sinus and the upper blood sinus. A bulge of connective tissue separates the two portions of the blood sinus. Summary diagrams have been provided by both of the studies cited above and can be consulted for the general pattern of organization.

Vibrissae or sinus hairs have been studied by electron microscopy dating from the initial studies of PAtrizi and Munger (1966), ANDRES (1966), ANDRES and VON DÜRING (1973) and YoHRo (1977). The first two studies identified Merkel cells as a prominent feature of this complex receptor. ANDREs (1966) also noted the presence of nerves at the apex of the sinus in a region where the capsule blends with the connective tissue around the external root sheath. At the time of writing these papers, we did not know of the complexity of sensory innervation of vibrissae. ANDRES (1966) also identified correctly lanceolate terminals in rat vibrissae at the level of the Merkel terminals. The lanceolate terminals are identical to those of guard hairs noted above.

The first suspicion that additional terminals were present was suggested by HALATA and MUNGER (1980a) who identified Ruffini terminals abutting the external root sheath in primate vibrissae. RENEHAN and MUNGER (1986a) also identified lanceolate terminals, Ruffini endings and FNEs in the conus region of rat vibrissae as well as some FNEs along the external root sheath at the level of the cavernous sinus. Thus the entire shaft of the vibrissal hair follicle is innervated.
We used the ultrastructural findings of RENEHAN and Munger (1986a) and were able to identify addional receptors as well in a variety of mammals (RICE et al., 1986). We thus confirmed the presence of simple corpuscles that had been noted by ANDRES (1966), but could not find them in all species. Simple corpuscles are common in cat vibrissae. RICE et al., (1986) also described a ring-like collar of Merkel terminals in the epidermis surrounding the opening of the follicle. Not all animals have this Merkel rete ridge collar, and the rabbit is the exception again as with guard hairs, it lacks the collar.

These marked species-specific differences have been correlated not only with the function of vibrissae themselves (NAKAI and SHIDA, 1948), but with the developmental phases of somatosensory cortex (RICE and MunGER, 1986). Based on the sequence of maturation of mystacial innervation and the hairs themselves, MUNGER and RICE (1986) have hypothesized that peripheral waves of differentiation may not only play a role in cutaneous differentiation, but may also play a role in the maturation of the central nervous system. Cutaneous sensory receptors have a unique role in peripheral neural development as well as forming the basis of one of our exteroceptive systems.

Acknowledgements. We thank Brian TUCKER for helping with the microscopy, Terri SEGNERI for helping in the final draft of the manuscript, and Dr. Terry JoNES for critically reading the manuscript.

\section{REFERENCES}

AIBA, L.: On the sensory innervation of the foot-sole in human adults. Arch. Histol. Jap. 10: 229-350 (1956).

AndREs, K. H.: Über die Feinstruktur der Rezeptoren und Sinushaaren. Z. Zellforsch. 75: 339-365 (1966).

ANDRES, K. H. and M. von DüRING: Morphology of cutaneous receptors. In: (ed. by) A. IGGO: Handbook of sensory physiology, Vol. II. Somatosensory system. Springer, New York, 1973 (p. 3-28).

BABLER, W. J.: Prenatal selection and dermatoglyphic patterns. Amer. J. Phys. Anthrop. 48 (1): 21-28 (1978).

Biemesderfer, D., B. L. Munger, J. Binck and R. DuBNer: The pilo-Ruffini complex: A non-sinus hair and associated slowly-adapting mechanoreceptor in primate facial skin. Brain Res. 142: 197: 222 (1978).

BuIx, M.: Experimentelle Beiträge zur Lösung der Frage über die spezifische Energie des Hautnerven. Z. Biol. 20: 56-141 (1884).

Bolanowski, S. J.: Intensity and frequency characteristics of Pacinian corpuscles. III. Effects of tetrodotoxin 
on the transduction process. J. Neurophysiol. 51: 813839 (1984).

BonNeT, J.: Studien über die Innervation der Haarbalge der Haustiere. Morphol. Jahrb. 4: 329-395 (1878).

Brenowitz, G. L., C. D. Tweedle, and J. I. Johnson : The development of receptors in the glabrous forepaw skin of pouch young opossums. Neuroscience. 5: 13031310 (1983).

Bressler, M. F. and B. L. Munger: Embryonic maturation of sensory terminals of primate facial hairs. J, Invest. Dermatol. 80: 245-260 (1983).

BYERS, M. R.: Sensory innervation of periodontal ligament of rat molars consists of unencapsulated Ruffinilike mechanoreceptors and free nerve endings. J. Comp. Neurol. 231: 500-518 (1985).

Castano, P. and R. G. Ventura: The Meissner's corpuscle of green-monkey (Cercopithecus aethiops L.). I. The organization of nervous component. J. Submicr. Cytol. 10: 327-344 (1978).

- : The Meissner's corpuscle of the green monkey (Cercopithecus aethiops L.). II. The connective tissue components. Some considerations from a functional standpoint. J. Submicr. Cytol. 11: 185-191 (1979).

Cauna, N.: Nerve supply and nerve endings in Meissner's corpuscles. Amer. J. Anat. 99: 315-350 (1956).

- Structure of digital touch corpuscles. Acta Anat. 32: 1-23 (1958).

-: The distribution of cholinesterase in the cutaneous receptor organs, especially touch corpuscles of the human finger. J. Histochem. Cytochem. 8: 367-375 (1960).

- : The free penicillate nerve endings of the human hairy skin. J. Anat. 115: 277-288 (1973).

Cauna, N. and G. Mannan : Development and postnatal changes of digital Pacinian corpuscles (Corpuscula lamellosa) in the human hand. Anat. Rec. 93: 271-286 (1959).

Cauna, and L. L. Ross: The fine structure of Meissner's touch corpuscles of human fingers. J. Biophys. Biochem. Cytol. 8: 467-482 (1960).

Chambers, M. R., K. H. Andres, M. von Düring and A. IGGo: Structure and function of the slowly adapting Type II mechanoreceptor in hairy skin. Quart, J. Exp. Physiol. 57: 417-445 (1972).

Chоuchкоv, C.: Ultrastructure of Pacinian corpuscles in man and cats. Z. Mikrosk.-anat. Forsch. 83: 17-32 (1971).

- Further observations of the fine structure of Meissner's corpuscles in human digital skin and rectum. Z. Mikrosk.-anat. Forsch. 87: 33-45 (1973a).

- The fine structure of small encapsulated re ceptors in human digital glabrous skin. J. Anat. 114: 2533 (1973b).

- : On the fine structure of Krause's end bulbs in human skin, oral cavity, and rectum. Arch. Histol. Jap. 35: 364-374 (1973c).

: Cutaneous receptors. Adv. Anat. Embryol. Cell Biol. 54: 7-61 (1978).
Crowe, R. and M. WhiteaR: Quinacrine fluorescence of Merkel cells in Xenopus laevis. Cell Tiss. Res. 190: 273-283 (1978).

Darian-Smith, I.: The sense of touch. Performance and peripheral neural processes. In: (ed. by) I. DARIANSMITH: Handbook of physiology. Sect. 1, III/2. Nervous system. Amer. Physiol. Soc., Bethesda, Maryland, 1984a (p. 595-788).

- Thermal sensibility. In: Ibid. 1984b (p. 879-913).

Dell, D. A. and B. L. Munger: The early embryogenesis of papillary (sweat duct) ridges in primate glabrous skin: The dermatotopic map of cutaneous mechanoreceptors and dermatoglyphics. J. Comp. Neurol. 244: 511-532 (1986).

Dellon, A. L.: Reinnervation of denervated Meissner corpuscles: A sequential histologic study in the monkey following fascicular nerve repair. J. Hand Surg. 1: 98109 (1976).

Dellon, A. L. and B. L. Munger: Correlation of histology and sensibility after nerve repair. J. Hand Surg. 8: 871-875 (1983).

Dellon, A. L., F. G. Witebsky and R. Terrill: The denervated Meissner corpuscle. A sequential histological study after nerve division in the rhesus monkey. Plast. Reconstr. Surg. 56: 182-193 (1975).

Diamond, I. T.: The subdivisions of neocortex: A proposal to revise the traditional view of sensory motor and association areas. Progr. Psychobiol. Psychol. 8: 243 (1973).

DogIEL, A. S.: Die Nervenendigungen in der Haut der äusseren Genitalorgane des Menschen. Z. Mikrosk.anat. Forsch. 41: 585-612 (1893).

: Über die Nervenendapparate in der Haut des Menschen. Z. Wiss. Zool. 75: 46-111 (1903).

Duboví, R. and P. ČERná: Evidence for the presence of different molecule forms of non-specific cholinesterase in Pacinian and simple sensory corpuscles. A histochemical and biochemical study. Scripta Med. 60: 51-60 (1987).

Dubový, R. and L. MalinovskÝ : Electron microscopic localization of cholinesterase activity in Pacinian corpuscles of the cat mesentery. Z. Mikrosk.-anat. Forsch. 96: 802-816 (1982).

Dykes, R. W.: Parallel processing of cutaneous information in the somatosensory system of the cat. J. Canad. Sci. Neurol. 9: 9-19 (1983).

English, K. B., D. K.-V. Norman and K. Horch: Effects of chronic denervation on Type I cutaneous mechanoreceptors (Haarscheiben). Anat. Rec. 207: 79-88 (1983).

Fujita, T.: Concept of paraneurons. Arch. Histol. Jap. 40 Suppl.: 1-12 (1977).

GoLDSCHEIDER, A.: Histologische Untersuchungen über die Endigungsweise der Hautsinnesnerven beim Menschen. Arch. Physiol. (Leipzig) Suppl.: 191-227 (1886).

GotTschaldT, K.-M. and C. VAHLE-Hinz: Evidence against transmitter function of met-enkephalin and chemosynaptic impulse generation in "Merkel cell" 
mechanoreceptors. Exp. Brain Res. 45: 459-463 (1982).

Gu, J., J. M. Polak, F. J. Tapia, P. J. Marangos and A. G. E. Pearse: Neuron-specific enolase in the Merkel cells of mammalian skin. Amer. J. Pathol. 101: 63-68 (1981).

Haiden, G. J. and E. A. Awad : The ultrastructure of the avian Golgi tendon organ. Anat. Rec. 200: 153-161 (1981).

Halata, Z. : Innervation der unbehaarten Nasenhaut des Maulwurfs (Talpa europaea). II. Innervation der Dermis (einfache eingekapselte Körperchen). Z. Zellforsch. 125: 121-131 (1972).

- : The mechanoreceptors of the mammalian skin: Ultrastructural and morphological classification. Adv. Anat. Embryol. Cell Biol. 50: 7-75 (1975).

: The ultrastructure of the sensory nerve endings in the articular capsule of the knee joint of the domestic cat (Ruffini corpuscles and Pacinian corpuscles). J. Anat. 124: 717-729 (1977).

: Postnatale Entwicklung sensibler Nervenendigungen in der unbehaarten Nasenhaut der Katze. Biblthca Anat. 19: 210-235 (1981).

Halata, Z. and B. L. Munger: Sensory nerve endings in rhesus monkey sinus hairs. J. Comp. Neurol. 192: 645663 (1980a).

- The sensory innervation of the primate eyelid. Anat. Rec. 198: 657-692 (1980b).

-: The ultrastructure of Ruffini and Herbst corpuscles in the articular capsule of domestic pigeon. Anat. Rec. 198: 681-692 (1980c).

- Identification of the Ruffini corpuscle in human hairy skin. Cell Tiss. Res. 219: 437-440 (1981).

- The sensory innervation of primate facial skin. II. Vermilion border and mucosa of the lip. Brain Res. Rev. 5: 81-107 (1983).

- The sensorineural apparatus of the human eyelid. Amer. J. Anat. 170: 181-204 (1984).

-: The neuroanatomical basis for the protopathic sensibility of the human glans penis. Brain Res. 371: 205-230 (1986).

Hale, A. R.: Morphogenesis of volar skin in the human fetus. Amer. J. Anat. 91: 147-181 (1952).

Hartschuh, W. and E. Weine: Fine structural analysis of the synaptic junction of Merkel cell-axon complexes. J. Invest. Dermatol. 75: 159-165 (1980).

Hartschuh, W., E. Weihe, M. Buchler, V. Helm Staedter, V. Feurle and W. G. Forssman: Metenkephalin-like immunoreactivity in Merkel cells. Cell Tiss. Res. 201: 343-348 (1978).

Hartschuh, W., E. Weihe, N. Yanaihara and M. REINECKE: Immunohistochemical localization of vasoactive intestinal polypeptide (VIP) in Merkel cells of various mammals: Evidence for a neuromodulator function of the Merkel cell. J. Invest. Dermatol. 81: 361364 (1983).

Hashimoto, K.: Fine structure of the Meissner corpuscle of human palmar skin. J. Invest. Dermatol. 60: 20-28,
(1973).

Head, H. and J. Sherren: The consequences of injury to the peripheral nerves in man. Brain 28: 116-338 (1905).

HebB, C. and K. J. Hill: Pseudocholinesterases in Pacinian corpuscles. Nature 175: 597 (1955).

Hensel, H.: Cutaneous thermoreceptors. In: (ed. by) A. IGGO: Handbook of sensory physiology, Vol. II. Somatosensory system. Springer, Berlin, 1973 (pp. 79110).

Hoggan, G. and F. E. Hoggan: Forked nerve endings on hairs. J. Anat. 27: 224-231 (1892/93).

Holbrook, K. A.: Structure and function of the developing human skin. In: (ed. by) L. E. Goldsmith : Biochemistry and physiology of the skin. Oxford, New York, 1983 (p. 64-101).

Horstmann, E.: Die Haut. In: (ed. by) E. von Möllen DORF: Handbuch der mikroskopischen Anatomie des Menschen, III/3. Haut und Sinnersorgane. Springer, Berlin, 1957 (p. 1-276).

IDE, C.: The fine structure of the digital corpuscle of the mouse toe pad, with special reference to nerve fibers. Amer. J. Anat. 147: 329-356 (1976).

: Development of Meissner corpuscle of mouse toe pad. Anat. Rec. 188: 49-67 (1977).

- Degeneration of mouse digital corpuscles. Amer. J. Anat. 163: 59-72 (1982a).

- Regeneration of mouse digital corpuscles. Amer. J. Anat. 163: 73-85 (1982b).

: Histochemical study of lamellar cell development of Meissner corpuscle. Arch. Histol. Jap. 45: 83-97 (1982c).

- Basal laminae and Meissner corpuscle regeneration. Brain Res. 384: 311-322 (1986).

: Role of extracellular matrix in the regeneration of a Pacinian corpuscle. Brain Res. 413: 155-169 (1987)

IDE, C. and S. HAYASHI: Specializations of plasma membranes in Pacinian corpuscles: Implications of mechano-electric transduction. J. Neurocytol. (1988, in press).

IDE, C., K. Kumagai and S. Hayashi: Freeze-fracture study of mechanoreceptive digital corpuscle of mice. J. Neurocytol. 14: 1037-1052 (1985).

IDE, C. and B. L. MUNGER: A cytologic study of Grandry corpuscle development in chicken toe skin. J. Comp. Neurol. 179: 301-324, 1978.

Ide, C., T. Nitatori and B. L. Munger: The cytology of human Pacinian corpuscles: Evidence for sprouting of the central axon. Arch. Histol. Jap. 50: 363-383 (1987).

IDE, C. and T. SAITo: Electron microscopic histochemistry of ATPase and alkaline phosphatase activities in mouse digital corpuscles. J. Neurocytol. 9: 207-218 (1980a).

- Electron microscopic cytochemistry of cholinesterase activity of mouse digital corpuscle. Acta Histochem. Cytochem. 13 : 218-226 (1980b).

- : Electron microscopic histochemistry of cholinesterase activity of Vater-Pacini corpuscle. 
Acta Histochem. Cytochem. 13 : 293-305 (1980c).

Ide, C. and K. Tohyama: Macrophages in Pacinian corpuscles. Acta Anat. 121: 110-114 (1985).

IDE, C., Y. Yoshida, S. HaYashi, M. Takashio and B. L. MUNGER: A re-evaluation of the cytology of Pacinian corpuscle. II. The extreme tip. Cell Tiss. Res. (1988, in press).

IGGo, A.: Cutaneous receptors. In: (ed. by) S. J. HubBARD: The peripheral nervous system. Pergamon, New YorkLondon, 208, 1974 (p. 351-353).

IGGO, A. and A. R. MUIR: The structure and function of a slowly adapting touch corpuscle in hair skin. J. Physiol. (Lond.) 200: 763-796 (1969).

ILYINSKY, O. B.: Process of excitation and inhibition in single mechanoreceptors (Pacinian corpuscles). Nature 208: 351-353 (1965).

Ilyinsky, O. B., G. N. Akoev, T. L. Krasnikova and S. I. ElMAN : $\mathrm{K}$ and $\mathrm{Na}$ ion content in the Pacinian corpuscle fluid and its role in the activity of receptors. Pflügers Archiv. (Europ. J. Physiol.) 361: 279-285 (1976).

Iwanaga, T., T. Fujita, Y. Takahashi and T. Naka JIMA: Meissner's and Pacinian corpuscles as studied by immunohistochemistry for S-100 protein, neuronspecific enolase and neurofilament protein. Neurosci. Lett. 31: 117-121 (1982).

Jirmanová, I. and I. Zelená: Uptake of horseradish peroxidase by sensory terminals of lamellated corpuscles in mouse foot pads. Acta Neuropathol. 52: 129-134 (1980).

Johnson, K. O. and G. D. LAмв: Neural mechanisms of spatial tactile discrimination: Neural patterns evoked by braille-like dot patterns in the monkey. J. Physiol. (Lond.) 310: 117-144 (1981).

Jones, T. E. and B. L. Munger: Early differentiation of the afferent nervous system in glabrous snout skin of the opossum (Monodelphis domestica). Somatosen. Res. 3: 169-184 (1985).

- Neural modulation of cutaneous differentiation: Epidermal hyperplasia and precocious hair development following partial neuralectomy in opossum pups. Neurosci. Lett. 79: 6-10 (1987).

KaAs, J. H., R. J. Nelson, M. Sur and M. M. Mer ZENICH: Organization of somatosensory cortex in primates. In: (ed. by) F. O. Schmidt, F. G. Worden, G. Adelman and S. G. Dennis: The organization of the cerebral cortex. M. I. T. Press, 1981 (p. 237-262).

Kandel, E. R. and J. M. Schwartz: Principles of neural science. Second Ed. Elsevier, New York, 1985.

KraUse, W.: Über Nervenendigungen. Z. Ration Med. 5 : 28-43 (1859).

- : Die Nervenendigung innerhalb der terminalen Körperchen. Arch. Mikrosk. Anat. 19: 53-136 (1881).

Kruger, L., E. R. Perl and M. J. Sedivec: Fine structure of myelinated mechanical nociceptor endings in cat hairy skin. J. Comp. Neurol. 198: 137-154 (1981).

Kurosumi, K.: Paraneuronic and related cells in the mammalian skin. In: (ed. by) R. E. Coupland and T. FUJITA: Chromaffin, enterochromaffin, and related cells.
Elsevier, Amsterdam-Oxford-New York 1976 (p. 171189).

Landmann, L. E. and Z. Halata : Merkel cells and nerve endings in the labial epidermis of a lizard. Cell Tiss. Res. 210: 353-357, (1980).

Lennie, P.: Parallel visual pathways: A review. Vis. Res. 20: 561-594 (1980).

LoEsch, D. Z.: Quantitative dermatoglyphics: Classification, genetics, and pathology. Oxford Monographs on Medical Genetics, Oxford University Press, Oxford-New York, 1983.

LoEWENSTEIN, W. R.: Mechano-electric transduction in the Pacinian corpuscle. Initiation of sensory impulses in mechanoreceptors. In : (ed. by) W. R. LOEWENSTEIN : Handbook of sensory physiology, Vol. 1. Principles of receptor physiology. Springer, New York, 1971 (p. 269290).

Loewenstin, W. R. and D. Molins: Cholinesterase in a receptor. Science 128: 1284 (1958).

Loewenstein, W. R. and R. Skalak: Mechanical transmission in a Pacinian corpuscle. J. Physiol. 182: 346-378 (1966).

Loewenstein, W. R., Y. Kanno and S. J. Socolar: The cell-to-cell channel. Fed. Proc. 37: 2645-2650 (1978).

Maeda, T., T. Iwanaga, T. Fujita, Y. Takahashi and S. KobaYASHI: Distribution of nerve fibers immunoreactive to neurofilament protein in rat molars and periodontium. Cell Tiss. Res. 249: 13-23 (1987).

Malinovský, L. and J. Sommerová: Die postnatale Entwicklung der Vater-Pacinischen Körperchen in der Fussballen der Hauskatze (Felis silvestris $f$. catus L.). Acta Anat. 81: 183-201 (1972).

Mathewson, R. C. and P. B. Nava: Effects of age on Meissner corpuscles: A study of silver-impregnated neurites in mouse digital pads. J. Comp. Neurol. 231: 250-259 (1985).

Meissner, G.: Beiträge zur Anatomie und Physiologie der Haut. Leipzig. Leopold Voss 47 : 2 (1853).

Merkel, F.: Über die Endigungen der sensiblen Nerven in der Haut der Wirbelthiere. Schmidt, Rostock, 1880.

Merzenich, N. M. and T. Harrington: The sense of flutter-vibration evoked by stimulation of the hairy skin of primates: Comparison of human sensory capacity with the responses of mechanoreceptive afferents innervating the hairy skin of monkey. Exp. Brain Res. 9: 231260 (1969).

Merzenich, N. M. and J. H. KaAs: Principles of organization of sensory perceptual systems in mammals. Prog. Psychobiol. Physiol. Psychol. 9: 2-42 (1980).

Midlo, C. and H. Cummins: Palmar and plantar dermatoglyphics in primates. Wistar Institute, Philadelphia, Pennsylvania, 1942.

Miller, M. R., H. J. Ralston III, and M. KasahaRa: The pattern of cutaneous innervation of the human hand. Amer. J. Anat. 102: 183-217 (1958).

Moll, R., I. Moll, and W. W. Franke: Identification of Merkel cells in human skin by specific cytokeratin antibodies. Different. 28: 136-154 (1984). 
: Formation of epidermal and dermal Merkel cells during human fetal skin development. J. Invest. Dermatol. 87: 779-787 (1986).

Moore, S. J. and B. L. MUNGER: The early ontogeny of the afferent nerves and papillary ridges in human digital glabrous skin. Submitted (1988).

Mršević, D., S. Stefanović and V. DJordjević: Beitrag zum Studium des Vorkommens und der Entwicklung von Vater-Pacinischen Lamellenkörperchen in der Analgegend des Menschen im Laufe der Interuterinentwicklung. Acta Anat. 72: 75-82 (1969).

Munger, B. L.: A phase and electron microscopic study of cellular differentiation in pancreatic acinar cells of the mouse. Amer. J. Anat. 103: 1-34 (1958a).

- : A light and electron microscopic study of cellular differentiation in the pancreatic islets of the mouse. Amer. J. Anat. 103: 275-312 (1958b).

: The intraepidermal innervation of the snout skin of the opossum. A light and electron microscopic study with observations on the nature of Merkel's “Tastzellen". J. Cell Biol. 26: 79-97 (1965).

- : Patterns of organization of peripheral sensory receptors. In: (ed. by) W. R. LOEWENSTEIN: Handbook of sensory physiology, I. Principles of receptor physiology. Springer, Berlin, 1971 (p. 523-556).

- Cytology and ultrastructure of sensory receptors in the adult and newborn primate tongue. In: (ed. by) J. F. Bosma: Development of fetus and infant, 73-546 DHEW Publication, 1973 (p. 75-95).

- Specificity in the development of sensory receptors in primate oral mucosa. In: (ed. by) J. F. BosmA: Development of upper respiratory anatomy and function: Implication for sudden and unexpected infant death. DHEW Publ. (NIH) 75-941, Bethesda: USDHEW, 1975a (p. 96-120).

- Cytology of mechanoreceptors in oral mucosa and facial skin of the rhesus monkey. In: (ed. by) R. O. BRADY: The nervous system. Vol. 1. The basic neurosciences. Raven Press, New York, 1975b (p. 71-79).

- : Multiple afferent innervation of primate facial hairs, Henry Head and Max von Frey revisited. Brain Res. Rev. 4: 1-43 (1982).

Munger, B. L. and Z. Halata: The sensory innervation of the primate facial skin. I. Hairy skin. Brain Res. Rev. 5: 45-80 (1983).

: The sensorineural apparatus of the human eyelid. Amer. J. Anat. 170: 181-204 (1984).

Munger, B. L. and C. Ide: The enigma of sensitivity in Pacinian corpuscles: A critical review and hyopthesis of mechano-electric transduction. Neurosci. Res. 5: 1-15 (1987).

Munger, B. L., R. B. Page and B. H. Pubols: Indentification of specific mechanosensory receptors in glabrous skin of dorsal root ganglionectomized primates (Abstract). Anat. Rec. 193: 630-631, (1979).

Munger, B. L. and L. M. Pubols: The sensorineural organization of the digital skin of the raccoon. Brain Behav. Evol. 5: 367-392 (1972).
Munger, B.L. and F. L. RICE: Successive waves of differentiation of cutaneous afferents in rat mystacial skin. J. Comp. Neurol. 252: 404-414 (1986).

Munger, B. L. and R. J. SchneIDER: Dissociated sensibility in human hairs following peripheral nerve injury, Henry Head confirmed (Abstract). Pain Meeting (1986).

Munger, B. L., Y. Yoshida, S. Hayashi, T. Osawa and C. IDE: A re-evaluation of cat Pacinian corpuscles. I. The inner core and clefts. Cell Tiss. Res. (1988, in press).

NaGaI, T.: Encapsulated sensory corpuscle in the mucosa of human vocal cord: An electron microscope study. Arch. Histol. Jap. 45: 145-153 (1982).

NakaI, J. and T. ShIDA: Sinus-hair of the sei-whale (Balaenoptera borcalis). Sci. Rep. Whal. Res. Inst. 1: 4147, 1948.

Ness, K. H., T. H. Morton, and B. A. Dale: Identification of Merkel cells in oral epithelium using antikeratin and antineuro-endocrine monoclonal antibodies. J. Dental Res. 66: 1154-1158, (1987).

Nishi, K., C. OURa and W. Pallie: Fine structure of Pacinian corpuscles in the mesentery of the cat. J. Cell Biol. 43: 539-553 (1969).

NitatoRI, T. : On the fine structure of human Golgi tendon organs as studied by three-dimentional observation. J. Neurocytol. (1988, in press).

Nurse, C. A. and J. Diamond: A fluorescent microscopic study of the development of rat touch domes and their Merkel cells. Neuroscience 11: 509-520 (1984).

Nurse, C. A., L. Macintyre and J. Diamond: A quantitative study of the time course of the reduction in Merkel cell number within denervated rat touch domes. Neuroscience 11: 521-533 (1984a).

: Reinnervation of the rat touch dome restores the Merkel cell population reduced after denervation. Neuroscience 13: 563-571 (1984b).

OchiaI, T. and H. Suzuki: Fine structure and morphometric studies of the Merkel cell during fetal and postnatal development. J. Invest. Dermatol. 77 : 437-443 (1981).

OKaJima, M. and Y. AsaI: Anatomical and microscopic study of the volar dermal ridges of the rat (Rattus norvegicus). Amer. J. Anthropol. 67: 81-88 (1985).

Pacini, F.: Nuovi organi scoperti nel corpo umano. Pistoja: Tipgrafia Cino, 1840.

Patrizi, G. and B. L. Munger: The cytology of encapsulated nerve endings in the rat penis. J. Ultrastr. Res. 13: 500-515 (1965).

- : The ultrastracture and innervation of rat vibrissae. J. Comp. Neurol. 126 : 423-436 (1966).

Pease, D. C. and W. Pallie: Electron microscopy of digital tactile corpuscles and small cutaneous nerves. J. Ultrastr. Res. 2: 352-365 (1959).

Pease, D. C. and T. A. Quilliam : Electron microscopy of the Pacinian corpuscle. J. Biophys. Biochem. Cytol. 3: 331-342 (1957).

Perez, A. P. R.: Contribution à la connaissance des terminaisons intersudorales. Trav. Lab. Rech. Biol. Univ. Madrid 27: 339-343 (1931/32). 
Perl, E. R.: Pain and nociceptors. In: (ed. by) I. DARIANSMith: Handbook of physiology, Sect 1, III/2: Sensory processes. Amer. Physiol. Soc., Bethesda, Maryland, 1984 (p. 739-788).

Pinkus, F.: Über Hautsinnesorgane neben dem menschlichen Haar (Haarscheiben) und ihre vergleichendanatomische Bedeutung. Arch. Mikrosk. Anat. 65:121179 (1905).

PoláčEK, P. and Z. Halata: Development of simple encapsulated corpuscles in the nasolabial region of the cat. (Ultrastructural study), Folia Morphol. (Prague) 18: 359-368 (1970).

PoláčeK, P. and L. MalinovskÝ : Die Ultrastruktur der Genitalköperchen in der Clitoris. Z. Mikrosk.-anat. Forsch. 84: 293-310 (1971).

PoláčEK, P. and K. MaZAnec: Ultrastructure of mature Pacinian corpuscles from the mesentery of adult cat. $Z$. Zellforsch. 73: 343-354 (1966).

Pubols, L. M., B. H. Pubols and B. L. Munger: Functional properties of mechanoreceptors in glabrous skin. Brain Res. 29: 47-61 (1971).

Quillium, T. A. and M. Sato: The distribution of myelin on nerve fibers from Pacinian corpuscles. J. Physiol. 129: 167-176 (1955).

Renehan, W. E. and B. L. Munger: Degeneration and regeneration of peripheral nerve in the rat trigeminal system. I. Identification and characterization of the multiple afferent innervation of mystacial vibrissae. J. Comp. Neurol. 246: 129-145 (1986a).

- Degeneration and regeneration of peripheral nerve in the rat trigeminal system. II. Response to nerve lesions. J. Comp. Neurol. 249: 429459 (1986b).

Rice, F. L., A. Mance and B. L. Munger: A comparative light microscopic analysis of the sensory innervation of the mystacial pad in the hamster, mouse, rat, gerbil, rabbit, guinea pig, and cat. I. Innervation of vibrissal follicle-sinus complexes. J. Com. Neurol. 252: 154-174 (1986).

RICE, F. L. and B. L. Munger: A comparative light microscopic analysis of the sensory innervation of the mystacial pad. II. The common fur between the vibrissae. J. Comp. Neurol. 252: 186-205 (1986).

Rivers, R. H. R. and H. HEAD: A human experiment in nerve division. Brain 31: 323-450 (1908).

SaIto, 0.: Studien über die Lamellenkörperchen. II. Entwicklung der lamellenkörperchen in Fersenteil des Menschenfötus (Japanese text with German abstract). Arch. Histol. Jap. 3: 441-4444 (1952).

SAKada, S. and H. AIDA: Electrophysiological studies of Golgi-Mazzoni corpuscles in the periosteum of the cat facial bones. Bull. Tokyo Dent. Coll. 12: 255-272 (1971a).

- Localization and shape of GolgiMazzoni corpuscles in the facial bones periosteum of the cat. Bull. Tokyo Dent. Coll. 12: 235-253 (1971b).

Samulack, D. D., B. L. Munger, R.W. Dykes and R. K. DANIEL: Neuronanatomical evidence of reinnervation in primate allografted (transplanted) skin during cyclosporine immunosuppression. Neurosci. Lett. 72: 16 (1986).

Sato, O., T. Maeda, S. Kobayashi, T. Iwanaga, T. Fujita and Y. TAkAhashi: Innervation of periodontal ligament and dental pulp in the rat incisor: An immunohistochemical investigation of neurofilament protein and glia-specific S-100 protein. Cell Tiss. Res. 251: 13-21 (1988).

Saurat, J.-H., P. Chavaz, P. Carraux and L. DidierJEAN: A human monoclonal antibody reacting with Merkel cells: Immunofluorescence, immunoperoxidase, and immunoelectron microscopy. J. Invest. Dermatol. 81: 249-253 (1983).

Saurat, J.-H., Y. Merot, L. DidierJean and D. Dahl: Normal rabbit Merkel cells do not express neurofilament proteins. J. Invest. Dermatol. 82: 641-642 (1984)

SAxoD, R.: Development of cutaneous sensory receptors in birds. In: (ed. by) M. JACOBSON : Handbook of sensory physiology, Vol IX. Development of sensory organs. Springer, Berlin, 1978 (p. 338-417).

Schoultz, T. W. and J. E. SwETT: Ultrastructural organization of the sensory fibers innervating the Golgi tendon organ. Anat. Rec. 179: 147-162, (1972).

ScotT, S. A., E. Cooper and J. DiAmond: Merkel cells as targets of the mechanosensory nerves in salamander skin. Proc. Roy. Soc. London 211: 453-470, (1981).

Seto, H.: Studies on the sensory innervation (Human sensibility). Igaku Shoin, Ltd., Tokyo, 1963.

Shanthaveerappa, T. R. and G. H. Bourne: New observations on the structure in Pacinian corpuscles and its relationship to the epithelium of peripheral nerves. Amer. J. Anat. 112: 97-109 (1963).

Silverman, R. T., B. L. Munger and Z. Halata: The sensory innervation of the rat rhinarium. Anat. Rec. 214: 210-255 (1986).

Smith, K. R. and B. J. CREech: Effects of pharmacological agents on the physiological responses of hair discs. Exp. Neurol. 19: 477-482 (1967).

SPAssova, I.: Ultrastructural relationship between the receptor nerve fiber and surrounding lamellae in Krause end-bulbs. Acta Anat. 109:360-368 (1981).

Spencer, P. S. and H. H. Schaumburg: An ultrastructural study of the inner core of the Pacinian corpuscle. J. Neurocytol. 2: 217-235, (1973).

STöнr, P.: Das peripherische Nervensystem. In: (ed. by) W. von MöllENDORFF: Handbuch der mikroskopischen Anatomie des Menschen, IV/1. Springer, Berlin, 1928 (p. 208-448).

Strasmann, T., Z. Halata and S. K. Loo: Topography and ultrastructure of sensory nerve endings in the joint capsule of the kowari (Dasyurides byrnei), an Australian marsupial. Anat. Embryol. 176: 1-12 (1987).

Suzuki, H. and K. Kurosumi: Fine structure of the cutaneous nerve endings in the mole snout. Arch. Histol. Jap. 34: 35-50 (1972).

Tachibana, T., Y. SakakuRa, K. Ishizeki, S. IIDA and T. 
NAwA: Migration of Merkel cells in the labial mucous epithelium of adult rabbits following mental nerve resection. Cell Tiss. Res. 223: 659-664 (1982).

experimental study of the influence of sensory nerve fibers on Merkel cell differentiation in the labial mucosa of the rabbit. Arch. Histol. Jap. 46: 469-466 (1983).

Tachibana, T., K. Ishizeki and Y. SakakuRa: Distinct types of encapsulated sensory corpuscles in the oral mucosa of the dog: Immunohistochemical and electron microscopic studies. Anat. Rec. 217: 90-98 (1987a).

Tachibana, T., Y. SakakURa, K. Ishizeki and T. Nawa : Nerve endings in the vermilion border and mucosal areas of the rat lip. Arch. Histol. Jap. 50: 73-85 (1987b).

Tohyama, $\mathbf{K}$ and $\mathbf{C}$. IDE: Carbonic anhydrase activity in axon terminals of sensory corpuscles. Arch. Histol. Jap. 50: 325-333 (1987).

Toyoma, Y.: The morphology of sensory corpuscles in the joint capsule. Ultrastructural and histochemical study (Japanese text with English abstract). J. Jap. Orthop. Ass. 59: 397-407 (1985).

Toyoshima, K., K. Miyamoto and A. Shimamura: The ultrastructure of encapsulated sensory corpuscles in the fungiform papillae of monkeys. Arch. Histol. Jap. 50: 385-392 (1987).

VATER, A.: Dissertation de consensu partium corpori humani. Haller, Disputationum anatomicarum selectarum, Gottingae, Vol. II, 1741.

von Frey, M.: Beiträge zur Physiologie des Schmerzsinns. Erste Mitt. Akad. Wiss. Leipzig, Math-Naturwiss. Kl. Ber. 46: 185-196, (1894a)

: Beiträge zur Physiologie des Schmerzsinns. Zweite Mitt. Akad. Wiss. Leipzig, Math-Naturwiss. Kl. Ber. 46: 283-296 (1894b).

- : Beiträge zur Sinnesphysiologie der Haut. Dritte Mitt. K. Sächsische Ges. Wiss. Ber. 47: 166-184 (1895).

W AGNeR, R. and M. MeISSNER: Über den Vorhandensein bisher unbekannten eigentümlicher Tastkörperchen (Corpuscula tactus) in den Gefühlswärzchen der menschlichen Haut und über die Endausbreitung sensitiver Nerven. Nachrichten von der Georg-August-Universität und der Königl. Gesellschaft der Wissenschaften zu Göttingen 2: 17-30 (1852).

WARR, W. B.: Parallel ascending pathways from the cochlear nucleus: Neuroanatomical evidence of functional specialization. Contrib. Sens. Physiol. 6: 1-38 (1982).

Watanabe, I. S. and E. Yamada: A light and electron microscopic study of lamellated nerve endings found in rat cheek mucosa. Arch. Histol. Jap. 48: 497-504 (1985).

WEDDELL, G.: The pattern of cutaneous innervation in relation to cutaneous sensibility. J. Anat. 75: 346-366 (1941).

: Studies related to the mechanism of common sensibility. In: (ed. by) W. Montagna: Advances in biology of skin. I. Cutaneous innervation. Pergamon, New York, 1960 (p. 112-160).

Weddell, G. and S. Miller: Cutaneous sensibility. Ann. Rev. Physiol. 24: 192-199 (1962).

Whitear, M. and B. LANe: Fine structure of Merkel cells in lampreys. Cell Tiss. Res. 220: 139-151 (1981).

WinkelmanN, R. K.: Nerve endings in normal and pathologic skin. Charles C. Thomas, Illinois, 1960.

Yamamoto, T., Y. Ito, H. Ueda and J. Yamaguchi: Sensory innervation of dorsum linguae in goat. Arch. Histol. Jap. 13: 547-558 (1957).

YHoro, T.: Structure of the sinus hair follicle in the big-clawed shrew, Sorex unguiculatus. J. Morphol. 153 : 333-354 (1977).

Yokota, R., C. Ide, T. Nitatori and S. ONOdera : Cholinesterase activity in the carotid sinus baroreceptors. Acta Histochem. Cytochem. 15: 537-542 (1982). the baroreceptors of the cat atrial endocardium. Acta Histochem. Cytochem. 16: 129-137 (1983).

Yoshida, Y., T. Ushiki, M. Takashio, B. L. Munger and C. IDE: Membrane relationships in murine Meissner corpuscles: The cytology of freeze-substituted tissue. Anat. Rec. submitted (1988).

Zelená, J.: The development of Pacinian corpuscles. J. Neurocytol. 7: 71-91 (1978).

- Rapid degeneration of developing rat Pacinian corpuscles after denervation. Brain Res. 187: 97-111 (1980).

-: Multiple innervation of rat Pacinian corpuscles regenerated after neonatal axotomy. Neuroscience 6: 1675-1686 (1981).

- The effect of long-term denervation on the ultrastructure of Pacinian corpuscles in the cat. Cell Tiss. Res. 238:387-394 (1984a).

- : Multiple axon terminals in regenerated Pacinian corpuscles of the adult rat. J. Neurocytol. 13: 665-684 (1984b).

Zelená, J. and T. Soukup: The development of Golgi tendon organs. J. Neurocytol. 6: 171-194 (1977).

Prof. Bryce L Munger

Department of Anatomy

The Milton S. Hershey Medical Center The Pennsylvania State University Hershey, Pennsylvania 17033

U. S. A. 